\title{
Combining implicit geological modeling, field surveys, and hydrogeological modeling to describe groundwater flow in a karst aquifer
}

\author{
Fernando M. D'Affonseca ${ }^{1,2} \cdot$ Michael Finkel $^{1} \cdot$ Olaf A. Cirpka $^{1}$ \\ Received: 12 February 2020 / Accepted: 22 July 2020 / Published online: 15 September 2020 \\ (C) The Author(s) 2020
}

\begin{abstract}
In three-dimensional (3-D) implicit geological modeling, the bounding surfaces between geological units are automatically constructed from lithological contact data (position and orientation) and the location and orientation of potential faults. This approach was applied to conceptualize a karst aquifer in the Middle Triassic Muschelkalk Formation in southwest Germany, using digital elevation data, geological maps, borehole logs, and geological interpretation. Dip and strike measurements as well as soil-gas surveys of mantel-borne $\mathrm{CO}_{2}$ were conducted to verify the existence of an unmapped fault. Implicit geological modeling allowed the straightforward assessment of the geological framework and rapid updates with incoming data. Simultaneous 3-D visualizations of the sedimentary units, tectonic features, hydraulic heads, and tracer tests provided insights into the karst-system hydraulics and helped guide the formulation of the conceptual hydrogeological model. The 3-D geological model was automatically translated into a numerical single-continuum steady-state groundwater model that was calibrated to match measured hydraulic heads, spring discharge rates, and flow directions observed in tracer tests. This was possible only by introducing discrete karst conduits, which were implemented as high-conductivity features in the numerical model. The numerical groundwater flow model was applied to initially assess the risk from limestone quarrying to local water supply wells with the help of particle tracking.
\end{abstract}

Keywords Implicit geological modeling $\cdot$ Numerical model $\cdot$ Karst $\cdot$ Conduit flow paths $\cdot$ Groundwater risk

\section{Introduction}

Understanding the geology is the backbone of any groundwater management project, since hydraulic heads and velocities, as well as flow trajectories and residence times, are strongly controlled by the properties and arrangement of lithological entities. The hydraulic connection between aquifers depends on their shape, arrangement, and internal structure (Raiber et al. 2015). Regional flow systems can be segmented by faults, which may form either barriers or preferential flow

Electronic supplementary material The online version of this article (https://doi.org/10.1007/s10040-020-02220-z) contains supplementary material, which is available to authorized users.

Olaf A. Cirpka

olaf.cirpka@uni-tuebingen.de

1 Center for Applied Geoscience, University of Tübingen, Hölderlinstr. 12, 72074 Tübingen, Germany

2 TIMGEO GmbH, Hölderlinstr. 29, 72074 Tübingen, Germany paths (Caine et al. 1996; Moya et al. 2014; Raiber et al. 2015). Groundwater models that are merely developed on hydraulic interpretations, while disregarding geological insights, are likely to be erroneous or untrustworthy (Fogg 1986).

Shaped by dissolution, internal erosion and subsidence processes, karst systems are commonly characterized by sinkholes, caves, springs, and conduits forming underground drainage systems (Ghasemizadeh et al. 2012). Although karst can develop from various evaporites, only limestone and dolostone karsts are relevant for water management purposes (Hartmann et al. 2014). Describing karst aquifers for the purpose of quantifying groundwater flow poses unique challenges due to the complex and highly uncertain arrangement of karst conduits where water flow often occurs under turbulent conditions at very high velocities (e.g., Jeannin 2001). Karst conduits comprise only a minor fraction of the total aquifer porosity but significantly control the aquifer hydraulics (e.g., Ghasemizadeh et al. 2012; Kuniansky 2016). Understanding the structure and hydraulic significance of 
fractures and conduits is therefore fundamental for the description of groundwater flow in karst aquifers. While the exact locations and properties of karst conduits are difficult to predict, their general orientation is strongly dominated by basic geological features such as the orientations of bedding planes, joints and faults, as well as the type and extent of the overburden, which strongly controls the karstification process (Ford 2003). To obtain an appropriate hydrogeological conceptual model of a karst aquifer, information on structural geology necessarily needs to be complemented by field observations and surveys such as tracer tests (e.g., Perrin and Luetscher 2008). This conceptualization is a crucial step, as numerical groundwater flow models built on flawed conceptual models inevitably produce inappropriate results (Bredehoeft 2005; Robins et al. 2005). Finally, the conceptual hydrogeological model can be evaluated and improved by a numerical flow model. If the calibrated numerical flow model cannot satisfactorily reproduce measured hydraulic heads and discharge rates, the conceptual geological model (definition of geological units, inclusion of faults, conduits geometry, etc.) needs to be revised.

Three-dimensional geological modeling consists of inferring a realistic spatial representation of the lithological bodies of the studied domain and other relevant features, such as faults, from sparse data and interpretations (Calcagno et al. 2008; Hassen et al. 2016; Pakyuz-Charrier et al. 2017; de la Varga et al. 2019). Several sources of data are usually employed, including borehole logs, geological maps, and geophysical data (Wellmann et al. 2010). A 3-D geological model is composed of various surfaces (e.g., strata contacts and faults) defining discrete volumes of geological units, that can subsequently be populated with petrophysical properties (Perrin et al. 2005) such as permeability and porosity. Inaccuracies are commonly related to data density and quality, geological complexity, interpretations, conceptual uncertainty, simplification requirements, and intrinsic randomness (Wellmann et al. 2010; Moya et al. 2014, Enemark et al. 2019).

Three-dimensional geological models are frequently employed to support decision-making, playing an important role in mining (Collon et al. 2015; Guo et al. 2016), oil and gas (Perrin et al. 2005), and geothermal exploration (Milicich et al. 2014; Collon et al. 2015), environmental management and hydrogeological surveys (Ross et al. 2005; Cox et al. 2013; Raiber et al. 2015), design of geotechnical constructions and nuclear underground-storage facilities (Živec and Žibert 2017), and evaluation of underground resources (Cherpeau et al. 2010), among other quantitative geoscientific applications (Hillier et al. 2016; Laurent et al. 2016; Pakyuz-Charrier et al. 2018). The modeling objectives can vary from spatial depiction of geological features to the generation of input data for physical-process simulations (Calcagno et al. 2008). In groundwater studies, 3-D geological modeling has been suitably used to support the conceptualization of flow regimes and to characterize groundwater recharge (e.g., Cox et al. 2013; Moya et al. 2014; Raiber et al. 2015; Hassen et al. 2016; Martinez et al. 2017; Raiber et al. 2019), and in the setup of numerical models (e.g., Fogg 1986; Martin and Frind 1998; Ross et al. 2005; Borghi et al. 2015). Modeling the fault network is of particular importance throughout 3-D geological modeling of bedrock aquifers, because faults can act as sealing barriers or drains, compartmentalizing and considerably influencing the subsurface flow (Cherpeau et al. 2010).

Over the last decades, various methods have been developed to construct 3-D models of geological objects (e.g. Gjoystdal et al. 1985; Lajaunie et al. 1997; de Kemp 1999; Cowan et al. 2003; Calcagno et al. 2008; Wellmann et al. 2010; Zou et al. 2012; Hillier et al. 2016; Burs et al. 2016; Guo et al. 2016; Martin and Boisvert 2017; Gonçalves et al. 2017; Riesner et al. 2017, de la Varga et al. 2019). Traditional 3-D geological modeling schemes are based on manual digitization of geological units within cross-sections. Simple to complex geometries can be generated by manually connecting two-dimensional (2-D) polylines across multiple sections. However, the intensive manual-drawing demand of this technique, known as explicit modeling, makes model updates a tedious and laborious task (Cowan et al. 2003; Vollgger et al. 2015; Guo et al. 2016). This is a substantial constraint, given that geological interpretations inevitably evolve as more data become available (Cowan et al. 2003). Consequently, the number of hypotheses that can be explored by explicit geological modeling while assessing and interpreting data is limited. Alternatively, geostatistical techniques can be employed, producing reasonable results for simple geometries. Complex shapes can be explicitly interpolated using triangulated irregular grids, but closely spaced sections and a high data density are required (Wellmann et al. 2010). EarthVision, GOCAD, Surfer, and Petrel are examples of software that apply an explicit geometric method, in which surfaces are represented by direct triangulation or interpolation (Burs et al. 2016).

Progress in 3-D interpolation techniques has favored the emergence of a practical alternative to explicit modeling, in which geological surfaces are quickly created by translating geological data into numerical values and subsequently applying computer algorithms (Cowan et al. 2003; Caumon et al. 2013; Vollgger et al. 2015; Burs et al. 2016). This scheme considers geological surfaces as isosurfaces of given functions, that are defined everywhere in space and built from the data location and orientation, besides some supplementary external constraints (Wellmann et al. 2010) such as the stratigraphy, fault geometry, hierarchy of stratal units, and contact types (deposits, erosions, intrusions, veins). This modeling approach is known as implicit modeling, because the explicit definition or digitization of surfaces is no longer required (Cowan et al. 2003). Nevertheless, polylines can still be defined to infer boundary positions, which are thereafter interpolated by the algorithm (Cowan et al. 2004). This way, complex geometries 
with arbitrary topology can rapidly be created by combining field data and geological interpretation (Alcaraz et al. 2011; Hillier et al. 2014). Three-dimensional implicit geological modeling has been gaining popularity over the last decade (Gonçalves et al. 2017). The major benefit of implicit modeling relies on its speed, which allows faster assessments of new information and uncertainty simulations, accordingly reducing the intrinsic risks of geological modeling (Cowan et al. 2003; Wellmann et al. 2010; Birch 2014; Vollgger et al. 2015). By comparing implicit and explicit geological modeling, Birch (2014) concluded that implicit modeling performs better than the traditional method of manual digitization. Additional benefits over explicit models comprise reproducibility, automation, and reduced user-based bias (Vollgger et al. 2015; Gonçalves et al. 2017). Moreover, the implicit function allows a fast and internally consistent 3-D model, which straightforwardly integrates multiple types of data such as lithological contacts and orientation, and structural constraints (Philippon et al. 2015; Vollgger et al. 2015). GeoModeller, Leapfrog, and Vulcan are examples of commercial software with implicit modeling capabilities (Burs et al. 2016).

Validating geological models constructed on restricted subsurface data is difficult; therefore, the consideration of regional insights facilitates the integration of surface observations and subsurface interpretations (Agar and Geiger 2015). Karst aquifers commonly present a hierarchically arranged network of linked fractures and conduits that may be drained by only one main spring (Hartmann et al. 2014). Thus, artificial tracer experiments with multiple injection points can provide valuable information on the structure of the karst-conduit network, especially combined with data on structural geology, spring hydrology, and speleological observations (Perrin and Luetscher 2008). Emanation of soil gases such as $\mathrm{Rn}, \mathrm{CO}_{2}$, and $\mathrm{He}$, are indicative of active faults (Lombardi and Voltattorni 2010). Although natural releases of $\mathrm{CO}_{2}$ can also be related to metamorphism, decomposition of organic material, and biological activity, elevated $\mathrm{CO}_{2}$ degassing seems to be associated with mantle emissions, active and ancient volcanism, and decarbonation processes (Lombardi and Voltattorni 2010). In areas with such characteristics, shallow soil $\mathrm{CO}_{2}$ degassing surveys may be used to delineate fault zones (e.g., Schütze et al. 2012; Lombardi and Voltattorni 2010), which may locally control flow-path directions (Perrin and Luetscher 2008).

Due to their specific heterogeneity, karst aquifers represent a special challenge for quantitative modeling (Hartmann et al. 2014). A multitude of approaches were proposed, from very simplistic black-box or lumped-parameter models in order to simulate rather phenomenologically the hydrologic dynamics of catchments and spring discharge (Butscher and Huggenberger 2008; Jukić and Denić-Jukić 2009; Tritz et al. 2011; Željković and Kadić 2015; Hosseini et al. 2017; and many others) to spatially distributed numerical models, which explicitly describe the groundwater flow using an equivalent porous medium approach (e.g., Ghasemizadeh et al. 2015; Borghi et al. 2016), a dual-continuum approach (e.g., Sauter 1993), or a discrete conduit-continuum approach (e.g., Kiraly 1979; Liedl et al. 2003; Shoemaker et al. 2008; de Rooij et al. 2013; Chen and Goldscheider 2014; Kuniansky 2016). Reviews on available model concepts are presented, e.g., by Kovács and Sauter (2007), Ghasemizadeh et al. (2012), and Kalhor et al. (2019).

This paper demonstrates how a spatially distributed model can be conceptualized, set up, and calibrated to describe groundwater flow in a karst aquifer by combining field surveys, 3-D implicit geological modeling, and an iterative model calibration method to reasonably consider hydraulically relevant karst conduits in the model. The paper describes the principal approach and its application to a Triassic limestone aquifer in southwestern Germany. The discussion sets a focus on the value of combining, integrating, and processing information and data from various sources to develop a geological and subsequently a hydrogeological model. This is done for the example of a preliminary assessment of possible risks from limestone quarrying for which a steady-state equivalent-porous-medium model was set up and calibrated to inform a particle tracker in order to estimate groundwater flow directions from existing quarries.

\section{Principal approach}

The proposed workflow combines the compilation of data, implicit geological modeling, field work, and the development of both a conceptual hydrogeological model and a numerical groundwater flow model, as visualized in Fig. 1. The first phase comprises the acquisition, compilation, and potential digitalization of topographical data (digital elevation models, DEMs), geological data (borehole logs, geological maps, etc.), and hydrogeological data (well construction profiles, hydraulic heads, location of springs and discharge rates, etc.). For the construction of a 3-D geological model, the surfaces to be represented in the model must be chosen in accordance with the main objectives of modeling and the given scale of the study area (Perrin et al. 2005). In order to define the site-specific hydrostratigraphy, hydrogeological relevant units are identified and, if appropriate, units with similar hydraulic properties are merged. If significant uncertainties arise or new interpretations are proposed, supplementary field work can be conducted to test the correctness of the geological model. Once the arrangement of geological objects in the model respects regional and local contexts, the history of possible geological events, and the field observations, i.e. once geological realism is considered reasonable based on the available data and knowledge, the model can be considered validated and is ready to be used to describe the primary spatial distribution of the properties (e.g., hydraulic conductivity, 
Fig. 1 Proposed workflow. Solid lines: mandatory steps; dashed lines: optional steps

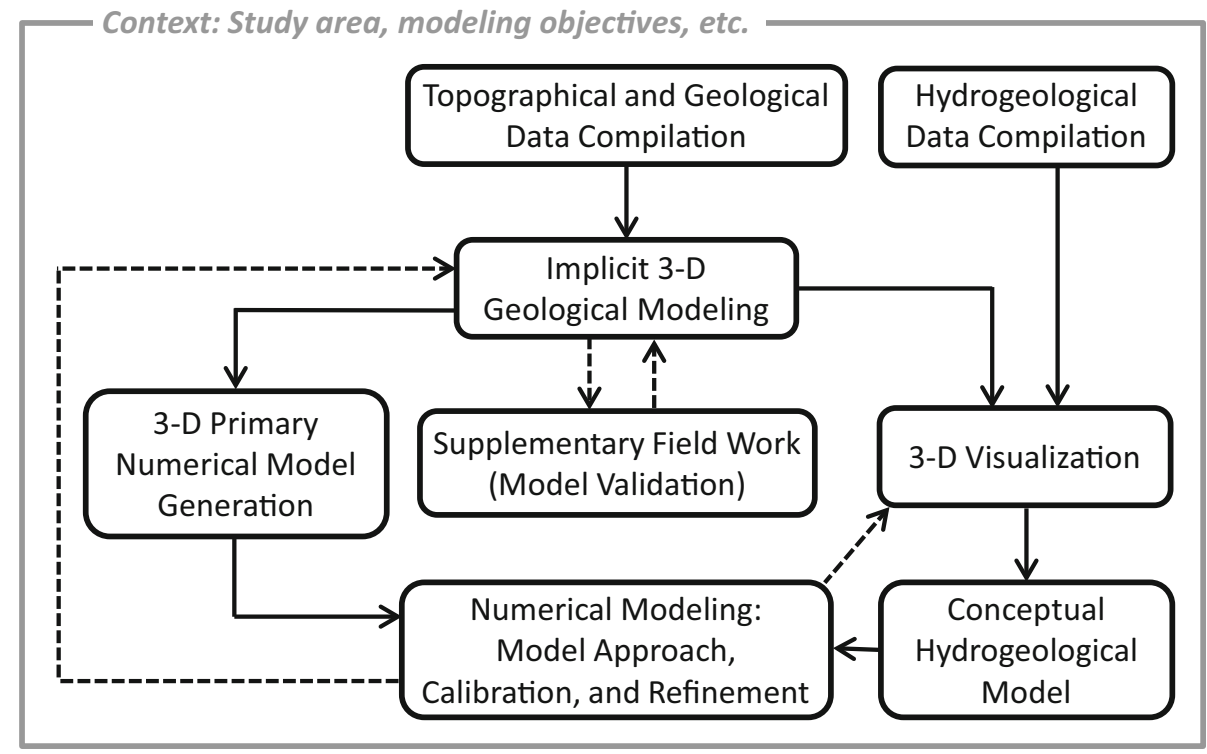

porosity, storage coefficient) of the numerical model. Additionally, the spatial representation of lithological entities can be used to assist the visualization of filter screens and hydrogeological data in three dimensions, e.g., potentiometric surfaces and tracer-test results. On this basis, a conceptual hydrogeological model can be developed that provides the necessary information for defining the boundary conditions of the numerical model. The selection of an appropriate numerical model approach should be part of this conceptualization. During the calibration process, further refinements of the numerical model's spatial parametrization can be conducted in an iterative way, i.e. using the geological model for visualization of interim simulations, including conceptualizations of the karst-conduit network. Eventually, the results of numerical modeling lead to additional geological insights. In early stages, a common conclusion drawn from the model results is that the existing numerical model cannot be calibrated. This may call for a review of the suitability of the chosen model approach or a revision of the conceptual hydrogeological model, or it requires a modification of the geological model. Such modifications may also be necessary when new data become available that are in contradiction to the current geological model. Depending on the data type and the magnitude of the misfit, new data may require only a re-calibration of the numerical model, a revision of the hydrogeological conceptualization, or a revision of the underlying geological model.

\section{Study area}

\section{Overview and previous work}

The outlined workflow was applied to a karst aquifer in southwest Germany. The study area is located between the mountain ranges of the Black Forest and the Swabian Alb (see Fig. 2). It covers the catchment of the Ammer River, a tributary of the Neckar River, and relevant neighboring catchments (total area approx. $750 \mathrm{~km}^{2}$ ). The geology comprises a sequence of Triassic and Jurassic strata with several prominent escarpments. The layers of the Upper Muschelkalk (mo), having a total average thickness of approx. $80 \mathrm{~m}$, together with the underlying 10-12-m-thick porous-to-cavernous uppermost dolomites of the Middle Muschelkalk ( $\mathrm{mm}$ ), form the main aquifer, which is used for the supply of drinking water by several municipalities. Shallow aquifers in fluvial deposits exist only locally.

The work presented in the following builds on the achievements of previous research addressing the geological and hydrogeological situation in the catchment of the Ammer River and its surroundings. Harreß (1973) mapped karst features and springs in the study area and carried out a large number of tracer tests to evaluate the risk from potential waste-water infiltration into the Muschelkalk aquifer. Reuther (1973) examined the tectonics and stratigraphy, and mapped the major faults in the study area. Villinger (1982) analyzed the tracer-test data of Harreß (1973) and further sources (unpublished), in combination with discharge measurement at the main springs and estimates of groundwater recharge, to consistently balance the groundwater budget of the catchment. Plümacher (1999) and Plümacher and Ufrecht (2000) described the regional groundwater flow in the Muschelkalk aquifer for a much larger area (ca. 4,500 $\mathrm{km}^{2}$ ). Selle et al. (2013) presented a numerical groundwater-flow model for the upstream part of the catchment, without considering any faults. Pavlovskiy and Selle (2015) analyzed environmental-tracer data at selected groundwater-abstraction wells to infer wellcatchment areas. 


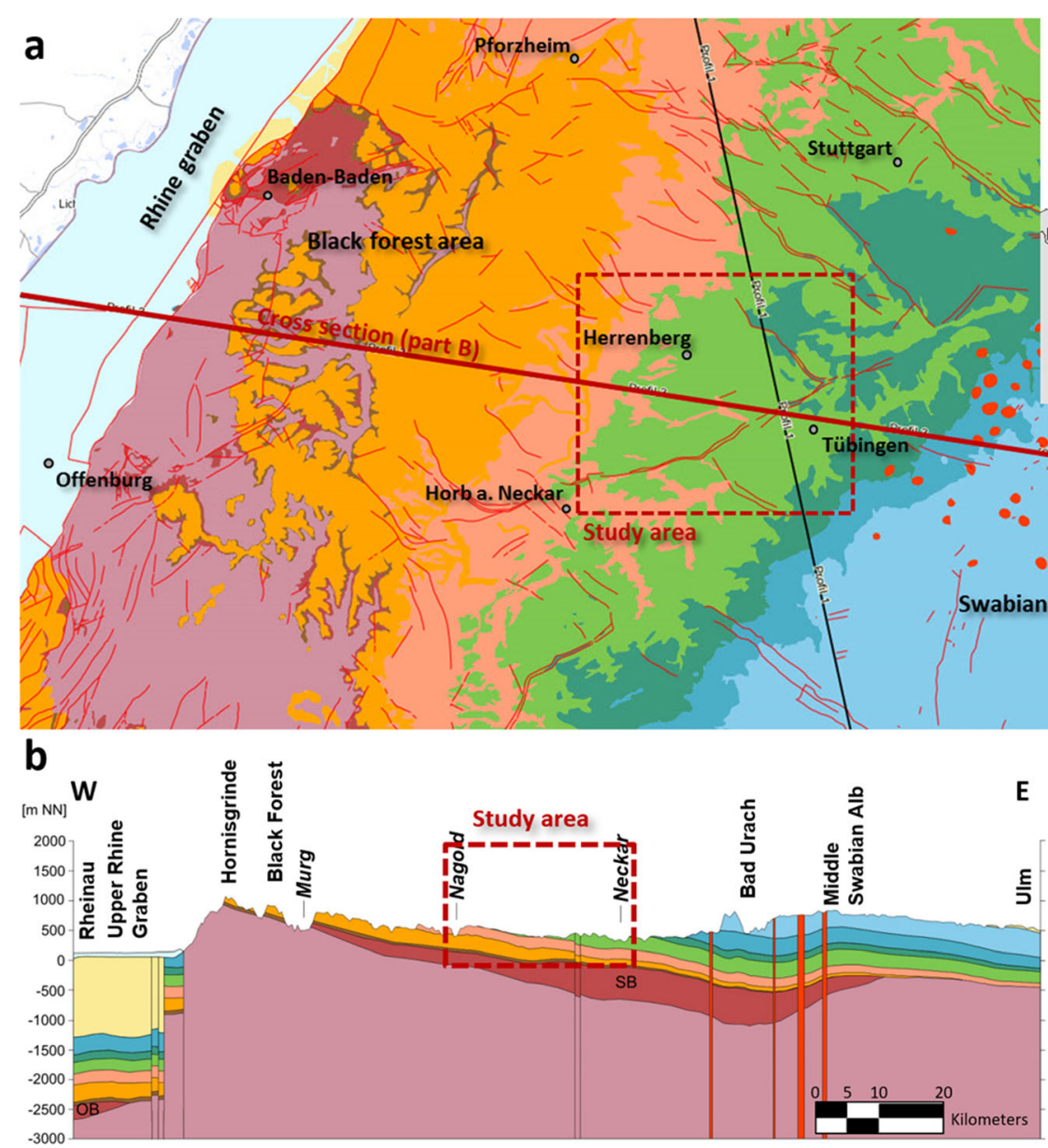

C

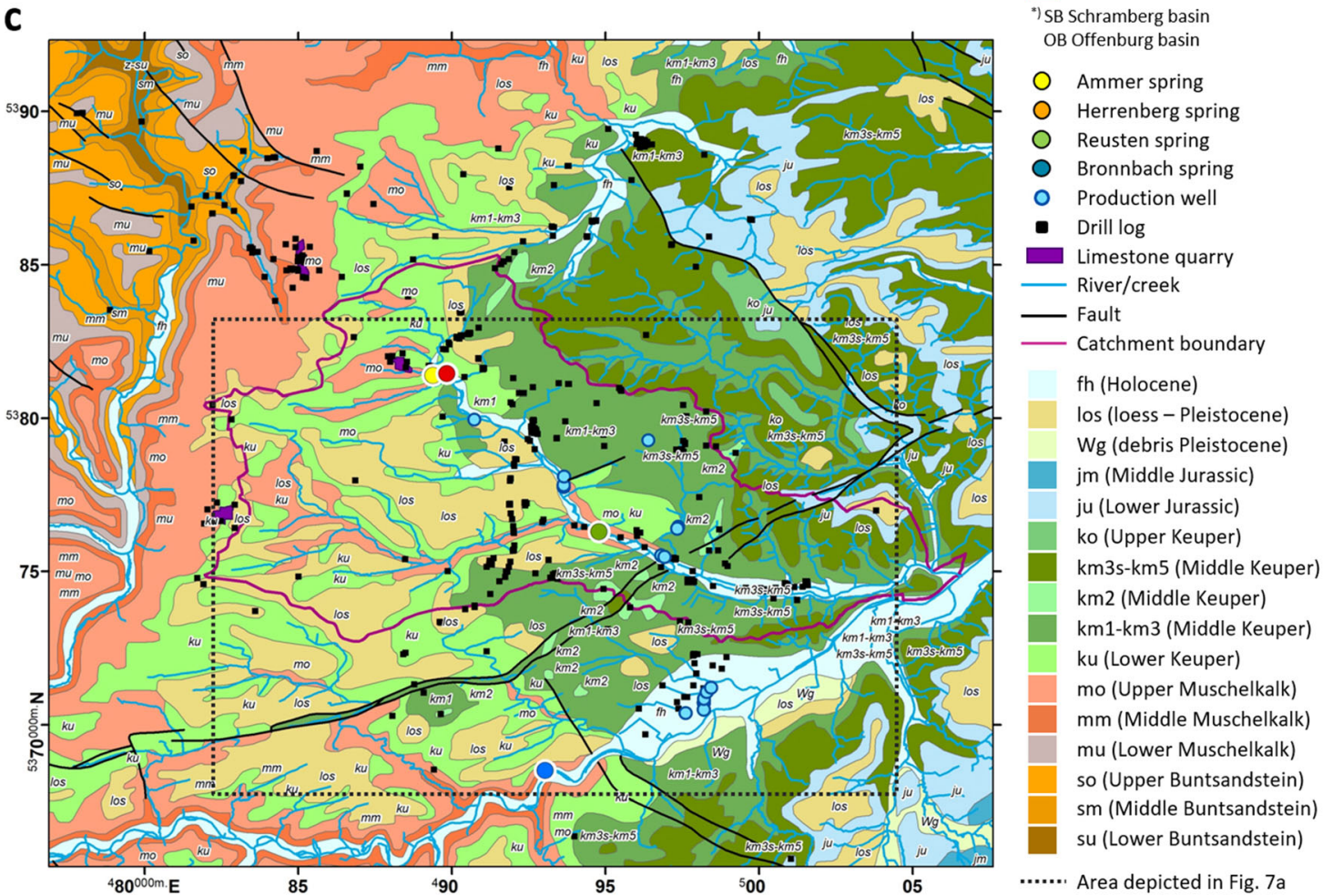

Fig. 2 a Location and geology of the study area, $\mathbf{b}$ cross-sectional view of geological units in the study area, and $\mathbf{c}$ location of particular features within the study area; coordinates: ETRS89-UTM32N; source: LGRB (1998) 


\begin{tabular}{|c|c|c|c|c|c|c|}
\hline Era & \multicolumn{4}{|c|}{ Period/Epoch/Formation/Subdivision } & Lithology ${ }^{(a, b)}$ & Thickness $[\mathrm{m}]^{(\mathrm{b})}$ \\
\hline \multirow{3}{*}{$\begin{array}{l}0 \\
0 \\
0 \\
0 \\
0 \\
0\end{array}$} & \multirow{3}{*}{ Quaternary } & \multicolumn{2}{|l|}{ Holocene } & $\mathrm{Fh}$ & Fluvial sediments & \\
\hline & & \multirow{2}{*}{\multicolumn{2}{|c|}{ Pleistocene }} & wg & Glacial debris & \\
\hline & & & & Lo & Loess & \\
\hline \multirow{15}{*}{$\begin{array}{l}0 \\
0 \\
0 \\
0 \\
\infty \\
\stackrel{\infty}{\infty}\end{array}$} & \multirow[b]{2}{*}{ Jurassic } & \multicolumn{2}{|l|}{ Middle } & $\mathrm{jm}$ & Opalinus claystones & \\
\hline & & Lower & & $\mathrm{ju}$ & $\begin{array}{l}\text { Claystones, shales, subordinate banks } \\
\text { of limestones, sandstones, bituminous } \\
\text { shales }\end{array}$ & $104-111$ \\
\hline & \multirow{13}{*}{ Triassic } & \multirow{7}{*}{ Keuper } & Upper & ko & Fine-grained sandstones and claystone & $0-10$ \\
\hline & & & \multirow{5}{*}{ Middle } & $\mathrm{km} 5$ & Red clays, marlstones & $30-40$ \\
\hline & & & & $\mathrm{km} 4$ & $\begin{array}{l}\text { Banks of soft calcareous sandstones } \\
\text { intercalated with shales }\end{array}$ & $25-60$ \\
\hline & & & & $\mathrm{km} 3$ & $\begin{array}{l}\text { Marly siltstones, subordinate medium- } \\
\text { grained sandstones }\end{array}$ & $25-35$ \\
\hline & & & & $\mathrm{km} 2$ & Fine sandstones, shales, dolomites & $0-12$ \\
\hline & & & & $\mathrm{kmGr}$ & $\begin{array}{l}\text { Gypsite layers, claystones, subordinate } \\
\text { sandstones, dolomites }\end{array}$ & $90-110$ \\
\hline & & & Lower & kuE & $\begin{array}{l}\text { Marlstones, shales, dolomites, } \\
\text { sandstones }\end{array}$ & $14-25$ \\
\hline & & \multirow{3}{*}{ Muschelkalk } & Upper & mo & $\begin{array}{l}\text { Limestones, dolomites, } \\
\text { marlstones/claystones }\end{array}$ & $80-87$ \\
\hline & & & Middle & $\mathrm{mm}$ & $\begin{array}{l}\text { Evaporites (anhydrite, gypsite), } \\
\text { dolomites }\end{array}$ & $30-75$ \\
\hline & & & Lower & $\mathrm{mu}$ & $\begin{array}{l}\text { Clayey limestones and dolomites, } \\
\text { dolomitic marlstones }\end{array}$ & $50-60$ \\
\hline & & \multirow{3}{*}{$\begin{array}{l}\text { Buntsand- } \\
\text { stein }\end{array}$} & Upper & so & $\begin{array}{l}\text { Quartz sandstones and claystones, } \\
\text { dolomites }\end{array}$ & $40-55$ \\
\hline & & & Middle & $\mathrm{sm}$ & $\begin{array}{l}\text { Quartz sandstones, rubble, } \\
\text { conglomerates }\end{array}$ & 180 \\
\hline & & & Lower & $\mathrm{su}$ & $\begin{array}{l}\text { Quartz sandstones, rubble, } \\
\text { conglomerates }\end{array}$ & 40 \\
\hline
\end{tabular}

Fig. 3 Stratigraphy of the study area. a Geological map (1:1,000,000): LGRB (1998). b Geological maps (1:25,000): GLA (1966, 1986, 1989, 1992, 1994a, b, c), LGRB (1996, 2005).

\section{Geological setting}

In the study area, Triassic and Jurassic strata gently dip toward SE (circa $1^{\circ}$ ), due to the Tertiary subsidence of the Alpine foreland Molasse basin and the uplift of the Black Forest crystalline basement (LGRB 2005). The elevation predominantly ranges from 300 to $600 \mathrm{~m}$ above sea level. Only in the southeastern corner of the study area, where the Middle Jurassic 
crops out, does the topography reach elevations of up to $800 \mathrm{~m}$.

Deposited in a cratonic basin, the Triassic sediments are subdivided into (1) Lower Triassic fluvial Buntsandstein, (2) Middle Triassic marine Muschelkalk, and (3) Upper Triassic partly marine, partly terrestrial Keuper (Hornung and Aigner 1999). The deep marine Jurassic sediments occur only at the eastern parts of the study area (Fig. 2), where the Lower and Middle Jurassic units are exposed. Pleistocene glacial unconformities overlaying the Mesozoic sediments frequently occur on the hills (loess) and hill slopes (talus), as well as in the valleys (drift sheet). The latter is mainly covered by Holocene alluvial deposits (GLA 1966; LGRB 1998). Figure 3 provides a short description of the main geological units outcropping in the study area.

Two major fault systems characterize the central Europe tectonics: (1) the pre-Variscan (characterized by the Erzgebirgisch SW-NE and the Swabian WSW-ENE direction) and (2) the post-Variscan (containing the Hercynian SE-NW and Rhenish SSW-NNE trends)(Petrovic 2016). The study area is specifically influenced by conjugate fault patterns formed by two large synthetic WSW-ENE fault zones, the Swabian lineament in the south and the NeckarJagst lineament in the north (Fig. 4), including antitheticfault confluences and intersections in between (Schwarz and Kilfitt 2008). Extensional, sinistral and high-angle SE-NW faults branch off to the north of the destral Swabian lineament, forming the Filder-Graben system, with three hanging walls. The footwall comprises the major portion of the study area (Fig. 4). Close to Tübingen, the SE$\mathrm{NW}$ fault zone separating the footwall from the upper hanging wall forms a confluence bow with branches while merging with the Swabian lineament, revealing rotational effects (Schwarz and Kilfitt 2008). In this linkage zone the Swabian lineament forms a graben, also known as Bebenhausen graben, with offsets varying from 80 to $100 \mathrm{~m}$. Commonly, the offsets along the Swabian lineament ranges from 20 to $30 \mathrm{~m}$ (Ufrecht 2006). The faults of this region are additionally characterized by a preferential degassing of carbon dioxide, probably emerging from deeper parts of the earth's crust (Harreß 1973; Schütze et al. 2012).

A karst system initiates and develops through a combination of processes such as dissolution (subrosion), erosion (corrosion) and incasion (collapse). Fractures are widened by dissolution and at a certain stage a critical point is achieved, with turbulent flow occurring and accelerating the enlargement of fractures. Eventually some fractures start to dominate the dissolution processes and large conduits and caves may evolve (Benson and Yuhr 2016). The area of potential karstification due to carbonate dissolution by infiltrated water is limited to the western part of the study area (Fig. 5), where the Upper Muschelkalk and uppermost dolomites of the Middle Muschelkalk are exposed or only weakly covered. It forms the major recharge area and is characterized by sinkhole fields, low drainage density, influent streams, and karst springs. Further towards ESE, i.e. following the strata dip, the Keuper overburden increases and the Muschelkalk aquifer gets increasingly confined (Villinger 1982; Ufrecht 2006), preventing the Upper Muschelkalk karstification (Pavlovskiy and Selle 2015). Karstification may also be locally favored by the degassing

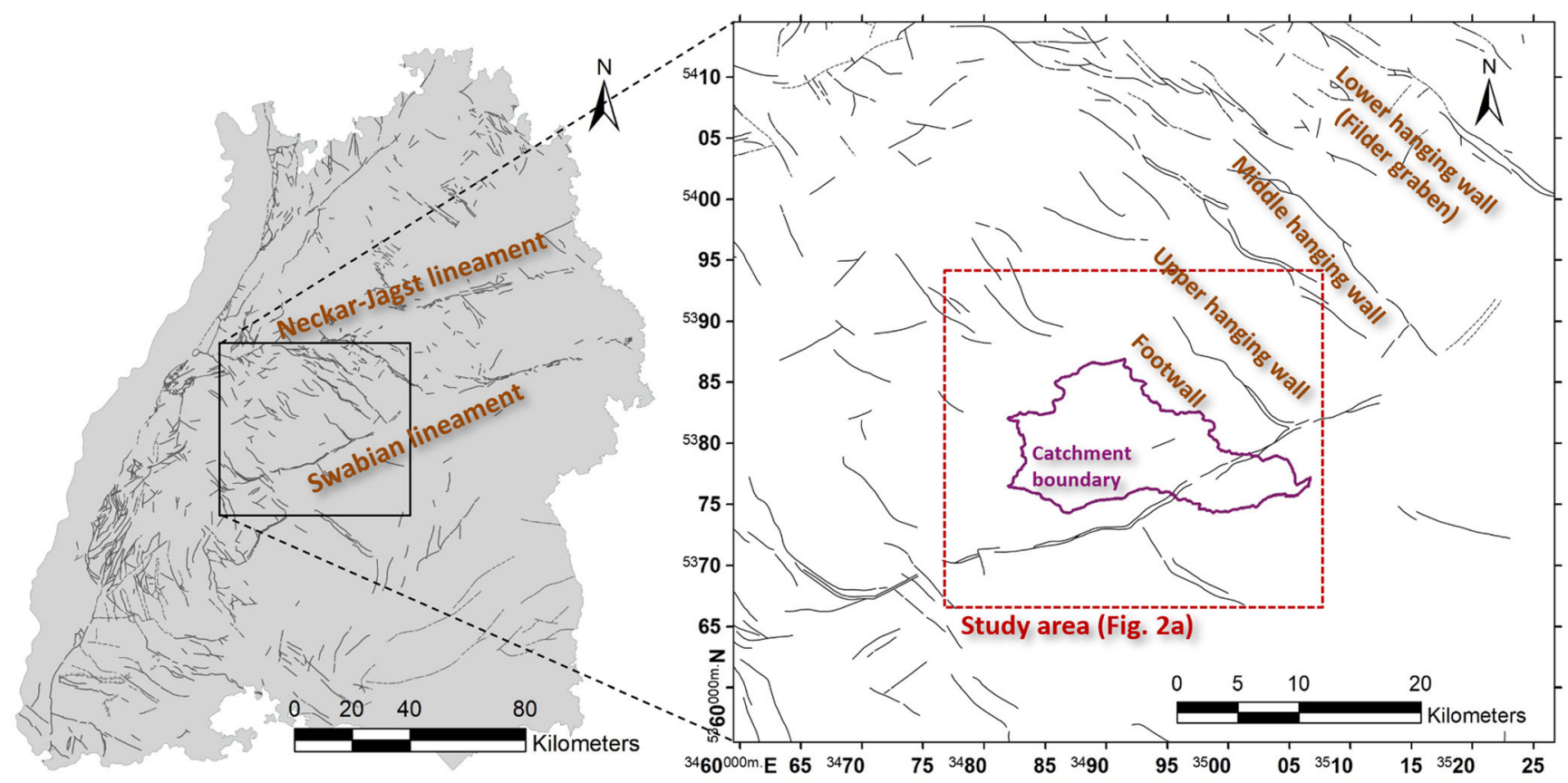

Fig. 4 Fault lines in Baden-Württemberg with details of the study area (source: LGRB 1998) 


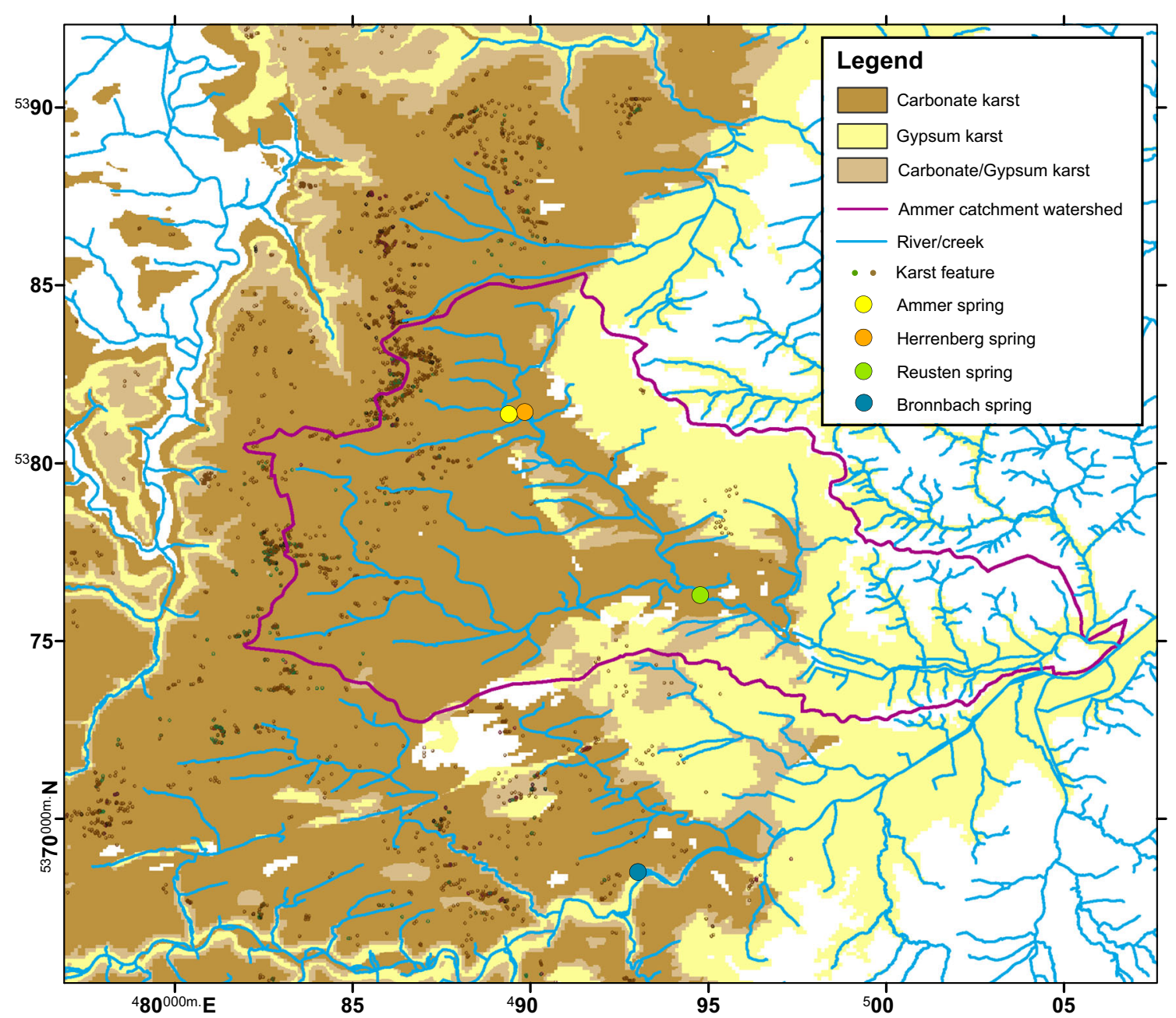

Fig. 5 Area of karstification and location of karst features (sinkholes, karst depressions, etc.) within the study area —as provided by the State Geological Survey (LGRB 2014); colors indicate data origin of karst features: brown = digital elevation model (DEM), green = soil map

of mantel-borne $\mathrm{CO}_{2}$ along faults (Harreß 1973), providing an additional structural control to the development of the karst-conduit network. Karstification also occurs in the gypsum-bearing Grabfeld formation (kmGr) due to dissolution of gypsum and anhydrite, but the Grabfeld formation and the Upper Muschelkalk are separated by the Erfurt formation $(\mathrm{kuE})$, which acts as an aquitard so that karstification of the Muschelkalk limestones and the Grabfeld gypsum is decoupled.

Sinkholes are by far the most frequent karst feature in the study area. The biggest one (the Herrgottsscheuer) is $30 \mathrm{~m}$ wide and $10 \mathrm{~m}$ deep. The open shaft is $14 \mathrm{~m}$ deep and SENW oriented. Only two caves are accessible. The biggest one (the Pommerlessloch) is at least $50 \mathrm{~m}$ long and SSW-NNE oriented (Harreß 1973). Although the described shaft and cave clearly present tectonic control, i.e. pre-Variscan and postVariscan orientations, respectively, the existing knowledge about the karst system does not allow one to discuss the role of individual joints and faults on the karstification process. Moreover, considering the classification proposed by
Waltham and Fookes (2003), the karst system can be classified as youthful, with drainage control and small sinkholes and caves.

\section{Hydrological and hydrogeological settings}

The annual mean precipitation in the study area ranges between 700 and $850 \mathrm{~mm}$ - Fig. S1 of the electronic supplementary material (ESM). Maximum values typically occur in summer. Storm events occur only rarely (average annual number of days with precipitation $>10 \mathrm{~mm} />20 \mathrm{~mm} />30 \mathrm{~mm}$ is approx. 20/4/1). The annual average air temperature is approximately $8{ }^{\circ} \mathrm{C}$.

The Upper Muschelkalk and the 10-12-m-thick permeable uppermost dolomites of the Middle Muschelkalk (Diemel Formation, mmD) form the Muschelkalk aquifer (Villinger 1982; Ufrecht 2006), the main groundwater reservoir in the study area. Internally, a 6-8-m-thick continuous limestonemudstone sequence occurring at the bottommost part of the Upper Muschelkalk, known as Haßmersheimer layers $(\mathrm{moH})$, 
hydraulically split the Muschelkalk aquifer into a basal and an upper part (Villinger 1982; Ufrecht 2006). Groundwater in the Muschelkalk aquifer mainly recharges in the outcropping areas in the western part of the study area, and roughly flows in a SE direction, following the strata dipping (Villinger 1982). In areas where the Muschelkalk is not covered by low-permeability strata, the aquifer recharge rate is approximately $220 \mathrm{~mm} /$ year.

Hydraulic conductivity values vary over several orders of magnitude for all formations considered. In the Upper Muschelkalk, hydraulic conductivity ranges from approx. $10^{-6}$ to $10^{-3} \mathrm{~m} / \mathrm{s}$ (Villinger 1982). The mean hydraulic conductivity in the Ammer area may be estimated to $4 \times 10^{-5} \mathrm{~m} / \mathrm{s}$ according to the transmissivities reported in Villinger (1982) (see also Plümacher 1999). The hydraulic conductivity of the Grabfeld formation ( $\mathrm{kmGr}$ ) depends on its weathering state and how strong gypsum has been leached. $\mathrm{kmGr}$ aquifers may have a very complex internal structure where, in extreme cases, impermeable, low-permeability and high-permeability zones can be found contiguously (Ufrecht 2017). Hydraulic conductivity values in leached and nonleached $\mathrm{kmGr}$ units range from $10^{-9}$ to $10^{-4} \mathrm{~m} / \mathrm{s}$ and from $10^{-13}$ to $10^{-5} \mathrm{~m} / \mathrm{s}$, respectively (Schlosser et al. 2007), with mean values between $10^{-6}$ and $2 \times 10^{-5} \mathrm{~m} / \mathrm{s}$ (Ufrecht 2017). The hydraulic conductivity of the Quaternary sediments within the Ammer and the Neckar valleys is on the order of $10^{-3} \mathrm{~m} / \mathrm{s}$ (e.g., Lessoff et al. 2010). Although sand and dolomite facies can build thin and localized aquifers within the Keuper units, the $\mathrm{km} 2, \mathrm{~km} 3, \mathrm{~km} 4$, $\mathrm{km} 5, \mathrm{~km} 5$, ko, as well as Lower Jura (ju) units play only a minor hydrogeological role in the study area, as they predominantly occur in forest areas at the Schönbuch plateau, where groundwater recharge is assumed to be low (Selle et al. 2013). Note that the drainage pattern clearly follows a WSW-ENE and SE-NW pattern (Fig. 6). Further eastwards, however, dendritic drainage patterns progressively develop, given the low permeability of the Upper Keuper and Lower Jurassic units.

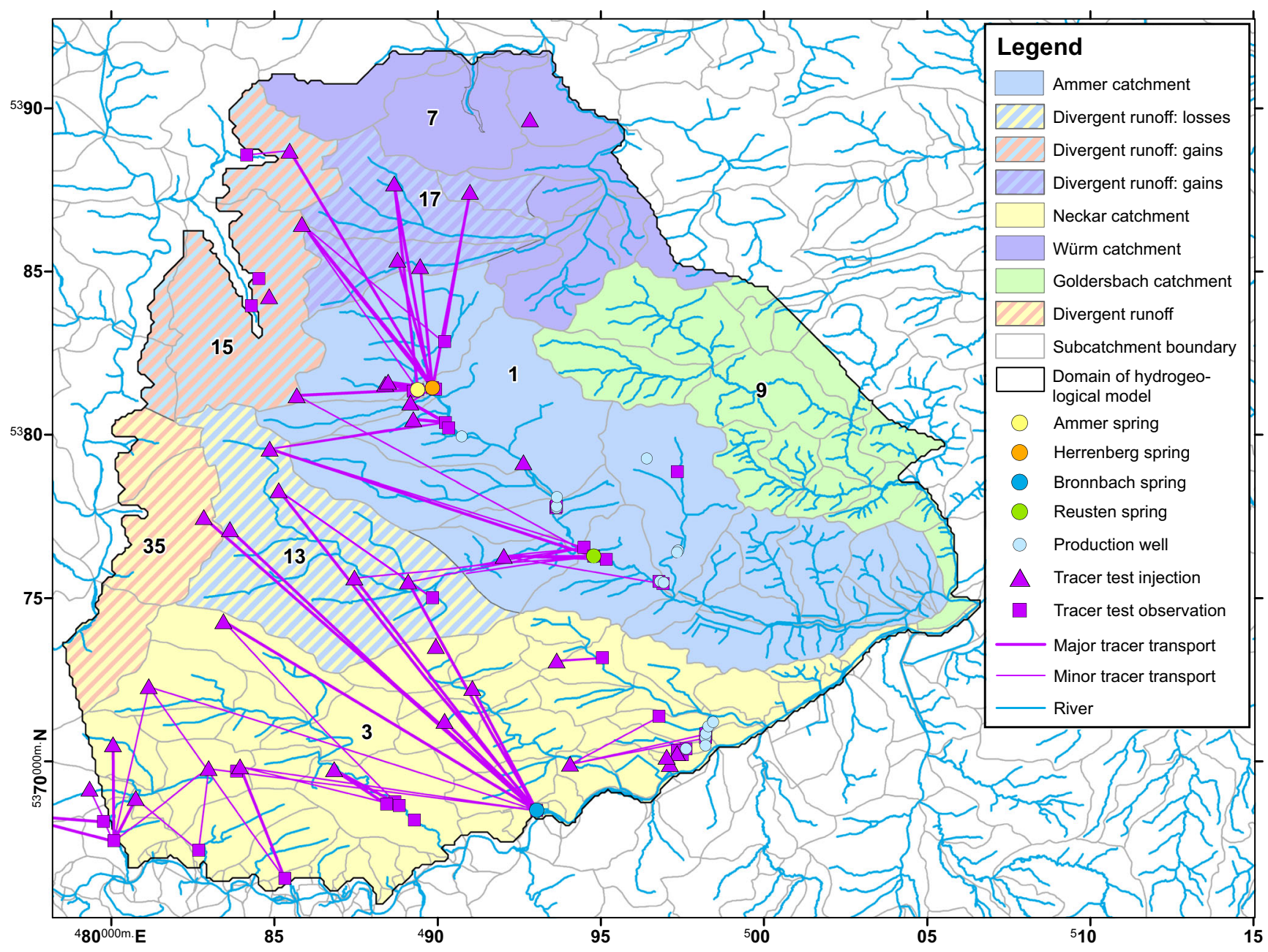

Fig. 6 Hydrological regime of the study area according to spring discharge data, river run-off data and tracer-test results (distinction between minor and major transport directions on a qualitative basis, see Harreß 1973). The subsurface catchment does not coincide with the topographic catchment of the Ammer River; areas of losses of water runoff to neighboring catchments, as well as of runoff gains from neighboring catchments, have been estimated based on tracer test results; numbers indicate IDs of zones used in the modeled water balance 
The evaporites of the Middle Muschelkalk characterize the lower boundary of the Muschelkalk aquifer. The Middle Muschelkalk is an aquitard that, together with the Lower Muschelkalk, regionally separates the Muschelkalk aquifer from the underlying Buntsandstein aquifer (Ufrecht 2006).

Over the last decades, a total of 35 tracer tests have been conducted in sinkholes, losing rivers, and dry valleys of the study area, in order to better characterize the Muschelkalk aquifer (Harreß 1973; Villinger 1982; GLA 1997). These tests reveal high flow velocities $(\sim 100 \mathrm{~m} / \mathrm{h}$ on average, $>200 \mathrm{~m} / \mathrm{h}$ maximum) and clearly show that the Ammer surface watershed mismatches the groundwater divides. Tracer compounds injected northward of the topographic divide were recovered in the Ammer catchment while tracers injected in the western part of the Ammer basin were found at the Bronnbach spring in the Neckar Valley south of the topographic Ammer catchment (Fig. 6).

The Muschelkalk aquifer naturally discharges to the Neckar and Ammer rivers, including their associated tributaries (Villinger 1982; Selle et al. 2013). Major perennial springs of the Muschelkalk aquifer are the Bronnbach spring (mean discharge: $530 \mathrm{~L} / \mathrm{s}$ ) at the southern edge of the study area, the Ammer spring, the Herrenberg spring (each approx. $15 \mathrm{~L} / \mathrm{s})$, and the Reusten spring $(\sim 10 \mathrm{~L} / \mathrm{s})$. These springs are examples of focused groundwater discharge through karst features. The Muschelkalk aquifer is used for drinking water supply. Groundwater abstraction wells are situated both in the Ammer and Neckar valleys with average pumping rates of 95 and $55 \mathrm{~L} / \mathrm{s}$, respectively (Ammertal-Schönbuchgruppe (ASG), unpublished data, 2012).

Low sulfate concentrations in these production wells suggest that the hydraulic connection between the Grabfeld formation and the Muschelkalk aquifer is weak, meaning that the lower-Keuper Erfurt formation (kuE) act as an aquitard prompting groundwater discharge from the overlaying Grabfeld formation aquifer (Pavlovskiy and Selle 2015). Using environmental tracers (tritium, SF6, and temperature), Pavlovskiy and Selle (2015) estimated mean water transit times to the groundwater abstraction wells ranging between 6 and more than 50 years.

\section{3-D geological modeling}

\section{Software and modeling procedure}

The geological modeling was carried out using the 3-D implicit modeling software Leapfrog (ARANZ Geo Limited 2016), which can be operated on conventional personal computers (Vollgger et al. 2015). Leapfrog uses the data and parameters supplied such as lithological codes, DEMs and drawn polylines, to implicitly construct surfaces based on spatial interpolation of the point attributes using radial basis functions (RBF) interpolation (Cowan et al. 2003; Alcaraz et al. 2011; Hillier et al. 2014; ARANZ Geo Limited 2016), which is mathematically identical to the function-estimate form of kriging. Multiple models conditioned on data can be built (Cowan et al. 2003). Leapfrog's hydrogeology module transfers the implicit geological model to input files of MODFLOW and FEFLOW.

\section{Data research and compilation}

Data on surface geology, including lithological contacts and tectonic structures, were gathered from nine geological maps at the scale of 1:25,000, in raster (GLA 1966, 1986, 1989, 1992, 1994a, b, c; LGRB 1996, 2005) and vector (GIS) format at the scale of 1:50,000 (LGRB 2012). For the subsurface geology, 463 boreholes were examined (LGRB 2020), in addition to known heights of the Quaternary unconformity at the Neckar Valley, between Rottenburg and Tübingen (LGRB 1999). The terrain's surface was represented by a DEM with 10-m resolution (LGL 2012).

The quality and relevance of the data were systematically evaluated. From the 463 boreholes inspected, 78 boreholes were subjected to stratigraphic interpretation and classification, while 53 were disregarded due to missing data or ambiguity. Finally, 410 irregularly distributed points were considered in the geological modeling (Fig. 2c), with depths varying from 1 to $392 \mathrm{~m}$. Although the average depth is $27 \mathrm{~m}$, approximately $77 \%$ of the boreholes are shallower, $50 \%$ are $20-30 \mathrm{~m}$ deep and only $4 \%$ are deeper than $100 \mathrm{~m}$.

\section{Definition of the model domain}

The geological model domain, i.e. the study area (as outlined in Fig. 2c), was defined such that given physical boundaries of the Muschelkalk aquifer are encompassed such as the bottom of the Muschelkalk aquifer in the western and northern parts of the study area, and the footwall border in the eastern part (Figs. 2 and 3), considering the offsets greater than $80 \mathrm{~m}$, at the northern portion of the SE-NW fault zone and along the Bebenhausen graben (Ufrecht 2006). To make sure that the geological model will fully cover the anticipated domain of the hydrogeological model, the southern boundary was set south of the Neckar River.

\section{Setting the site-specific hydrostratigraphy}

The geological model incorporates the entire local stratigraphy of the Triassic (Buntsandstein, Muschelkalk, and Keuper), and the Lower and the Middle Jurassic, as well as the major Quaternary alluvial and talus bodies. Loess deposits, which are typically thin in the study area, were not individually considered in the model but are accounted for in the quantification of recharge. Because the Lower and Middle 
Muschelkalk mostly act as aquitards, they were unified. Similarly, the $\mathrm{km} 2, \mathrm{~km} 3, \mathrm{~km} 4, \mathrm{~km} 5, \mathrm{~km} 5$, and ko units were also grouped, as well as the Jurassic units.

\section{3-D implicit geological modeling}

Given that geological and geophysical data are inherently uncertain and often scattered, no geological representation can be inferred from the data without a preceding geological interpretation (Perrin et al. 2005). In order to gather an initial understanding of the site geology, as well as to identify inconsistencies, all imported data were promptly visualized and evaluated in three dimensions. Unlike the explicit modeling method, which typically requires the construction of cross sections and the explicit digitization of surfaces, the surfaces are automatically generated from the spatial distribution of lithological contacts and orientation in 3-D implicit geological modeling. As the boreholes are rather irregularly distributed in space (Fig. $2 \mathrm{c}$ ), the modeling process required significant interpretation to assist the model interpolation in data-scarce areas, which were manually added by drawing points and polylines inferring geological contacts in the subsurface. Hence, the development of the model was driven by both data and geological knowledge.

The modeling process started with a very simple setting, i.e. discontinuities (faults) were successively added as necessary to achieve a parsimonious model, as simple as possible and as complex as necessary. Faults can be defined in Leapfrog using polylines or GIS vectors to create vertical walls or surfaces, interacting with each other based on the faults' chronology and interactions. Faults divide the geological model into individual blocks. Each block has its own and independent surface chronology, attributes, and spatial interpolation, meaning that hard data (borehole logs and lithological contacts extracted from the geological maps) and inferences of one block do not influence the surfacing of neighboring blocks.

Faults were manually incorporated in the model by firstly digitizing polylines representing their strikes on the DEM. Due to the high-angle characteristics of the faults in the study area, all faults in the model were represented by vertical walls $\left(\operatorname{dip}=90^{\circ}\right)$ for the sake of simplicity. In Leapfrog, a fault must extend to another fault or to the model boundaries. Fault extensions are modeled based on the interpreted fault chronology (e.g., older faults are not allowed to cross younger faults). Where modeled faults exceeded their known fault extension, care was taken to avoid offsets between neighboring blocks beyond the known faults' length. In data-scarce areas, subsurface lithological boundaries were inferred below mapped contacts based on the estimated average thickness of the strata.

\section{Supplementary field work, model refinement}

Field campaigns were conducted to investigate areas where the available data presented ambiguity or high uncertainty as well as to verify raised new hypotheses. For instance, in the central part of the study area, discrepancies between the $1: 25,000$ geological maps in raster at the scale of 1:25,000 (GLA 1966) and vector formats at the scale of 1:50,000 (LGRB 2012) were verified, with respect to the location of the top of the lower Keuper (kuE) formation on the Ammer Valley slopes. A gamma-ray well logging, conducted in a 60m-deep artesian well, supposedly cutting the lower Keuper (kuE) and Muschelkalk aquifer (results not shown), indicated that the raster map (GLA 1966) indeed better depicts the local geology, which was then used as a reference to control the geological model outputs.

In another area, the log description of two neighboring boreholes, the surface geology and the local geomorphology (local creek alignment and direction of the escarpment erosion front) indicate the existence of an unmapped $\mathrm{S}-\mathrm{N}$ oriented fault (Fig. 7). This postulated fault, however, was not in accordance with the site synthetic WSW-ENE and antithetic SE-NW fault trends. In order to assess the plausibility of the suggested S-N oriented fault, dip and strikes measurements were carried out at a former gypsum quarry close to Käsbach Creek. The identified high-angle SW-NE to SSE-NNW fractures, in agreement with synthetic and the postulated fault trend, respectively, provided substantial indications that the existence of a N-S fault is reasonable. The postulated S-N fault was finally validated by two subsequent soil- $\mathrm{CO}_{2}$-mapping profiles, considering that site faults commonly emanate mantel-borne $\mathrm{CO}_{2}$ (Harreß 1973; Schütze et al. 2012) and the fact that volumetric $\mathrm{CO}_{2}$ concentration peaks $(\sim 13 \%)$ in the soil gas were measured a few meters apart from the interpreted fault location (Fig. 7c,d). This fault may represent an S-N element, connecting two synthetic faults, which originated at a late stage of internal rotation of the footwall block in a transpressional environment. A detailed analysis of this tectonic feature is beyond the scope of this paper.

Further unmapped faults were inferred, considering the surface geology and borehole data, where available (Fig. 7a). These faults were identified by unrealistic shapes, e.g. ripples, on the modeled surfaces.

A pair of long and curved faults (ESE-WNW) was interpreted forming a down-dropped block with modest offsets $(<20 \mathrm{~m})$ just southward of the Mötzingen quarry (see western part of Fig. 7a). This interpretation is in agreement with Reuther (1973) who also inferred the existence of such faults using soil $\mathrm{CO}_{2}$ mapping. Junginger (2019) recently measured radon concentrations at the Ammer River in Poltringen (see central part of top-left map in Fig. 7), where a fault was postulated, providing additional evidences that one or more active faults intersect the Ammer River and that the interpretations upon which the model was constructed are reasonable.

The postulated antithetic SE-NW faults are roughly parallel to the direction of maximum compression of the active 


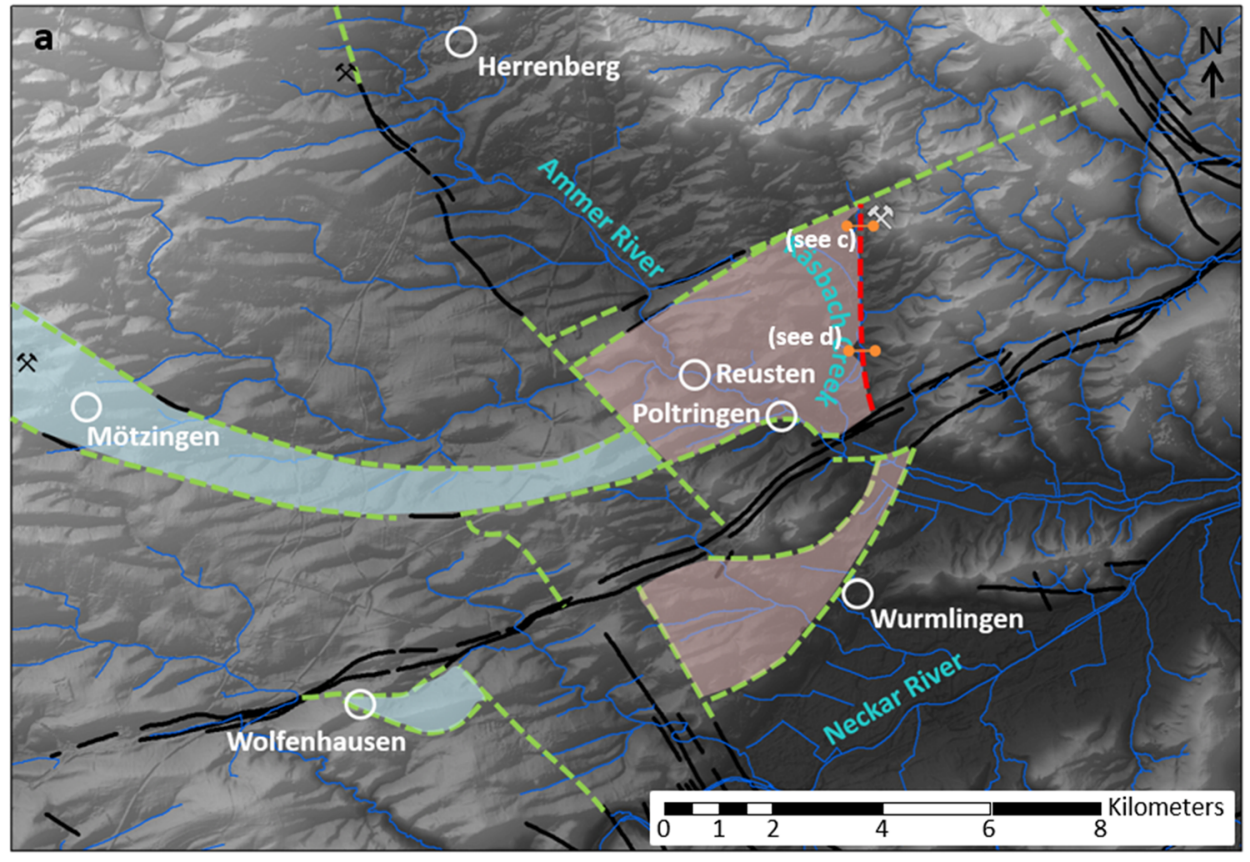

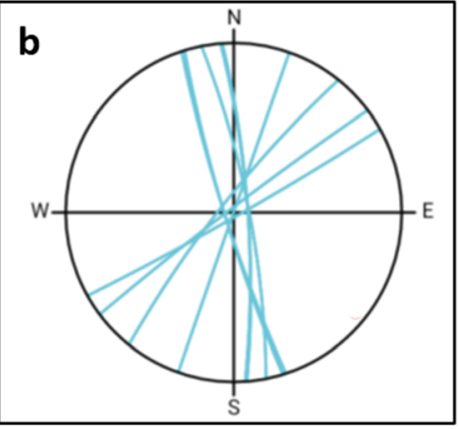

Legend

Former gypsum quarry

x Limestone quarry

-- Postulated faults

....* Verified fault

- Known faults

Rivers/Creeks

Raised block

Down-dropped block

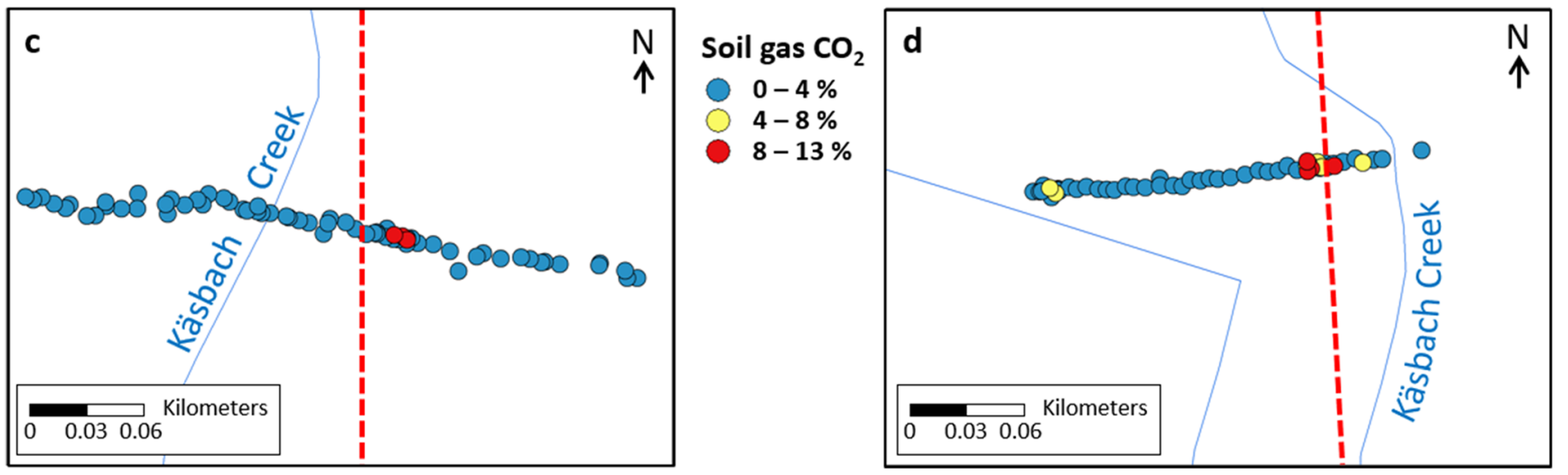

Fig. 7 a Postulated, verified and known faults and tectonic elements (raised and down-dropped blocks) in the center of the area of interest (see Fig. 2c for a better orientation), $\mathbf{b}$ stereographic projections of measured fractures, and $\mathbf{c}$ northern and $\mathbf{d}$ southern soil $\mathrm{CO}_{2}$ profiles crossing Käsbach Creek

stress field (about $140^{\circ}$ ), from the Alpes towards its northern foreland, according to Illies et al. (1981). The interpreted synthetic WSW-ENE curved faults are parallel and associated to the Swabian lineament.

In Wolfenhausen, the postulated synthetic faults indicate the existence of a local down-dropped block with offsets around $80 \mathrm{~m}$, as was also inferred by Villinger (1982). Close to Wurmlingen, however, the postulated synthetic faults form a raised block. Maybe these slip-strike features represent negative and positive flower transpressional structures, respectively.

Once the main lithological surfaces and model features were set, the relevant hydrofacies, i.e. the upper dolomite of the Middle Muschelkalk (mmD) and the Haßmersheimer layers (moH) of the Upper Muschelkalk, were modeled, using the top of the Middle Muschelkalk surface as reference and applying downward and upward constant offsets, respectively. A constant thickness of $12 \mathrm{~m}$ was assumed for $\mathrm{mmDol}$. Although $\mathrm{moH}$ consist of an upper and lower marl layer, separated by limestone, they were merged to a single 6$\mathrm{m}$-thick layer in the model, occurring $7 \mathrm{~m}$ above the bottom of Upper Muschelkalk (mo). Figure 8 shows the final geological model, which served as the basis for the subsequent hydrogeological modeling.

\section{Hydrogeological modeling}

\section{Conceptual model}

In order to develop the conceptual hydrogeological model of the study area, all relevant data and information were compiled, processed, and visualized within Leapfrog. Vadose, phreatic, and confined zones were delineated by intersecting 


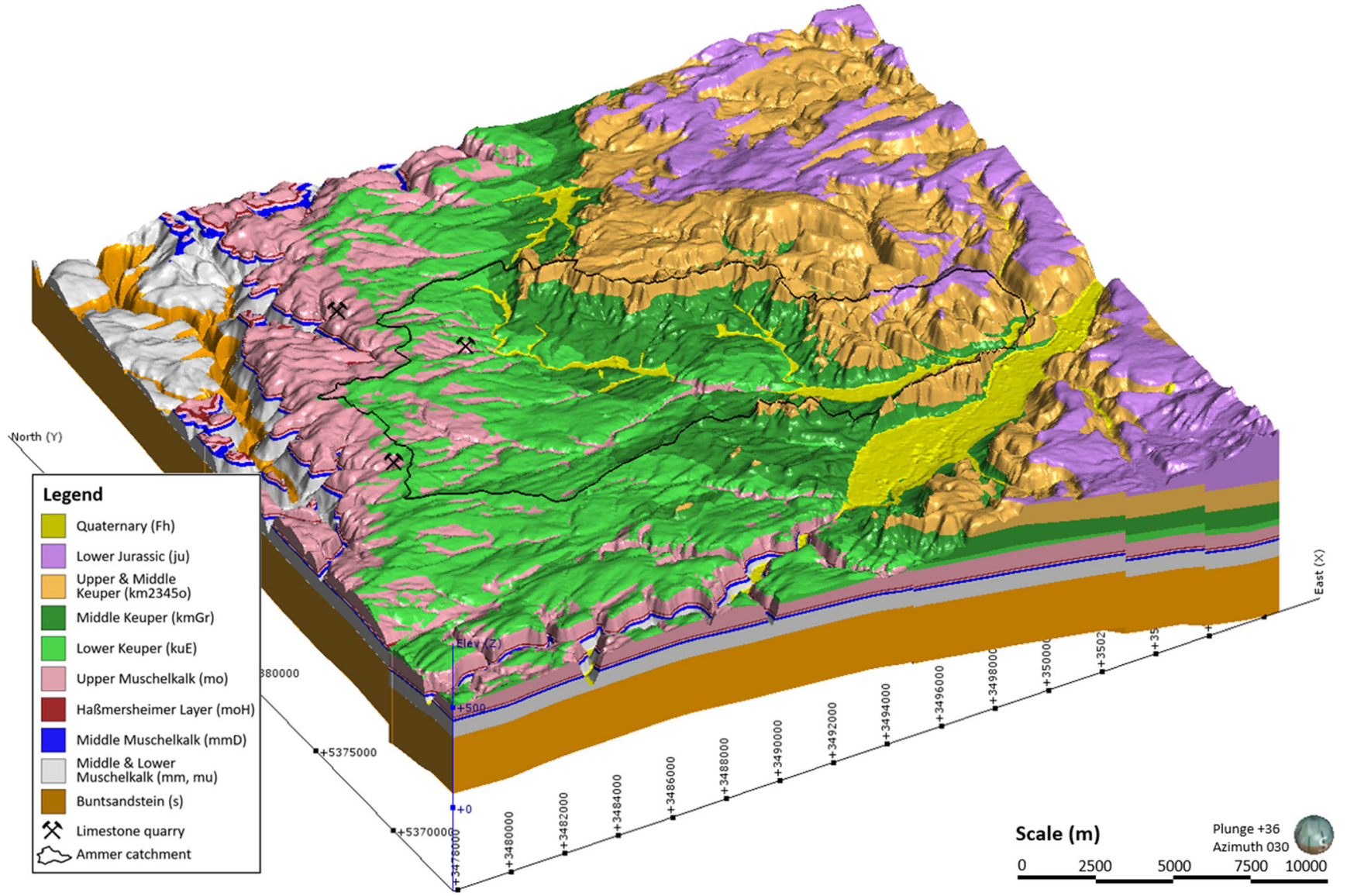

Fig. 8 Three-dimensional representation of the geological model

the hydraulic-head surface with the elevations of the aquifer base and top (as represented in terms of geological contacts in the 3-D geological model). Figure 9 shows the overlay of these features, providing a clear picture of the situation.

With the Triassic layers progressively dipping towards the southeast, hydraulic conditions in the Muschelkalk aquifer change in the same direction, from vadose (i.e. unsaturated) to phreatic, and finally confined conditions. Along the Neckar Valley in the south of the model domain, northern and southern groundwater flow regimes converge. Given the offsets of the extensional antithetic SE-NW faults, separating the footwall from the upper hanging wall, as well as the Bebenhausen graben along the Swabian Lineament, it can be assumed that groundwater outflow in the study area occurs under confined conditions between the Swabian Lineament and the Neckar Valley.

In the most western part of the study area, where the Upper Muschelkalk is exposed or its overburden is thin, the Upper Muschelkalk is a vadose zone. This region is the major recharge area of the modeled aquifer. Here sinkholes emerge due to carbonate dissolution and underlying subrosion of evaporites in the Middle Muschelkalk (Fig. 5). Following Hartmann et al. (2014), such sinkholes, with their associated subsidence fractures, probably lead infiltrated water directly to the basal part of the Muschelkalk aquifer, thus recharging groundwater below the Haßmersheimer layers. The level of the water table is in the upper dolomite of the Middle Muschelkalk, and the saturated thickness and hydraulic transmissivity of the aquifer are rather low. In dry periods, the groundwater body might even be absent in some areas. In the southeasterly direction, the thickness of the saturated zone continuously increases, and flow in the Upper Muschelkalk is first phreatic below, and then above the Haßmersheimer layers (where it starts to be confined below them). Further southeast, the Muschelkalk aquifer becomes fully confined, with the two horsts being exceptions.

While a large part of groundwater is recharged in the basal part of the Muschelkalk aquifer, it discharges predominantly in the upper part (springs, wells and rivers are all located above the Haßmersheimer layers). This applies also to the tracer tests, which were predominantly injected in sinkholes and most likely reached the basal aquifer part, but were recovered in receptors located above the $\mathrm{Haßmersheimer} \mathrm{layers} \mathrm{at}$ high recovery rates (up to $80 \%$ ). The 3-D geological model helps to determine likely tracer propagation paths. To illustrate this by an example, a tracer test is considered, that showed a propagation over the distance of about $13 \mathrm{~km}$ within $\sim 5$ days from the point of injection in the western part of the 


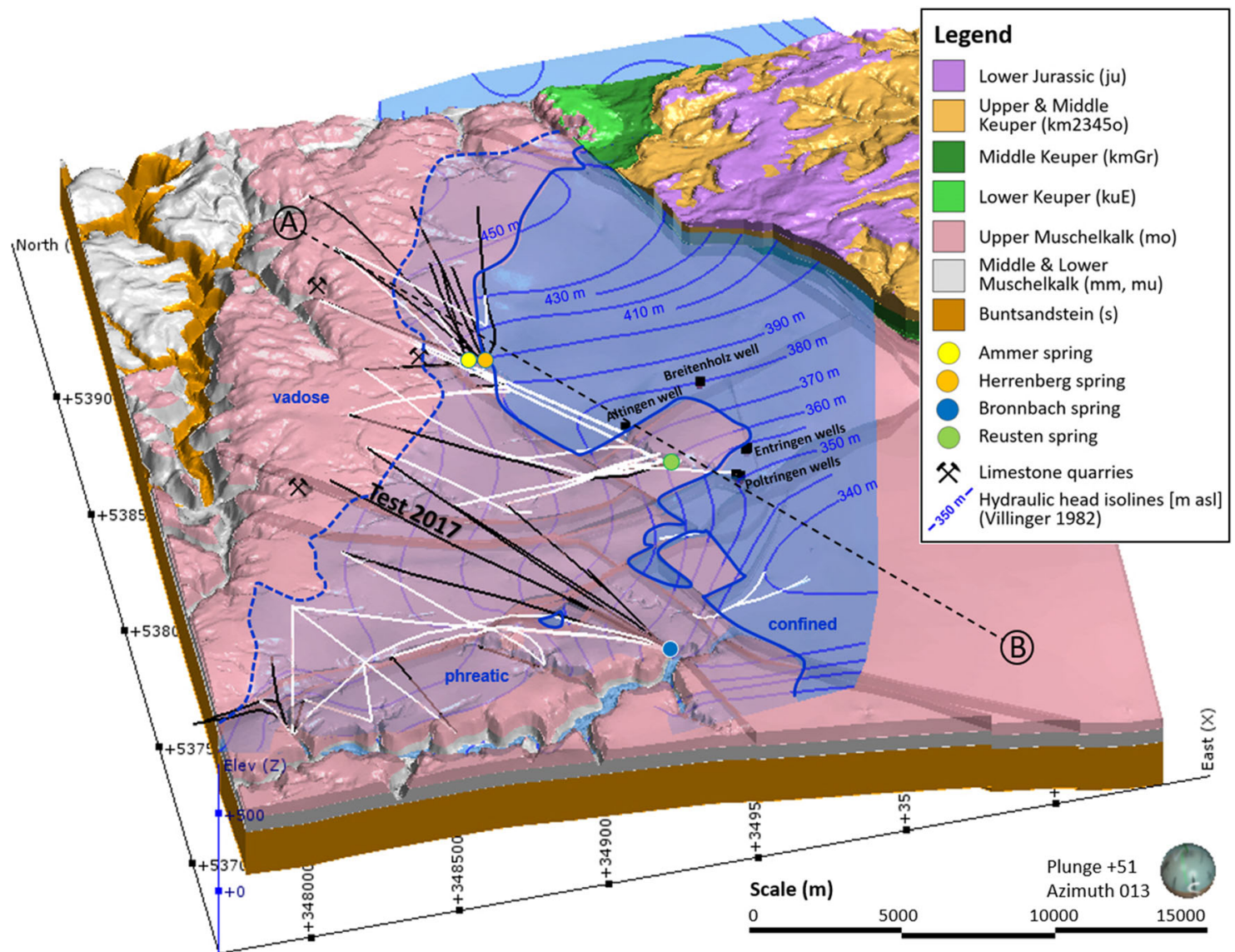

(A)

(B)

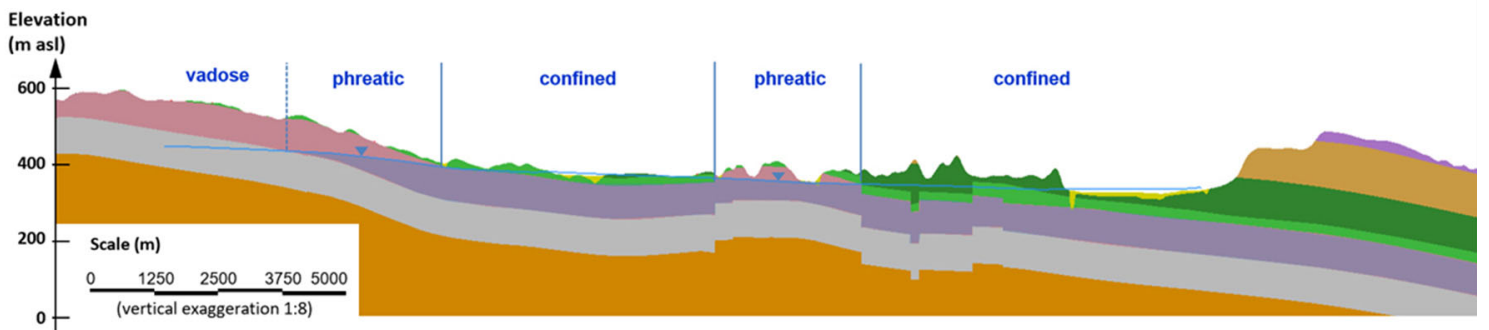

Fig. 9 Hydrogeological conditions in the Upper Muschelkalk aquifer (3D representation within Leapfrog). The dashed blue line indicates the transition between vadose and phreatic conditions, while the solid blue line indicates the transition between phreatic and confined conditions for average hydrologic conditions; note the two indentations corresponding to horst structures and the isolated confined area, due to a down-dropped

study area to the Bronnbach spring (labelled as "Test 2017" in Fig. 9). The injected tracer possibly migrated through the basal part of the Muschelkalk aquifer until reaching an extensional fault that hydraulically connects basal and upper parts of the Muschelkalk aquifer (Fig. 10). Further downgradient, the tracer most likely bypassed the Wolfenhausen graben (see Fig. 9), migrating eastward of it and reaching the Bronnbach spring through the postulated antithetic fault. Please note that similar conceptualizations may be done for other tracer tests conducted in the western part of the study area. block near Wolfenhausen with expressive faults offset (see Fig. 7). Black and white lines represent tracer test results with major and minor recovery rate, respectively (Harreß 1973, Villinger 1982). Faults appear as translucent gray walls. Beyond the Filder graben system in the northeast, the entire overlaying model stratigraphy is shown

The flow lines reflected by the tracer experiments are oriented mostly in the SE-NW direction (Fig. 9). Although in shear-zone domains, synthetic faults tend to be partially opened and antithetic faults compressed (Schwarz and Kilfitt 2008), the combined alignment effect of the SE bedding dip and SE-NW antithetic faults, as well as the kinetically related fracture sets, probably played an important role in the competitive formation of karst conduits. Bedding planes may play a more significant role for karstification than joints and faults, as their greatest apertures tend to be more continuous than those of fractures (Ford 2003). Moreover, the hydraulic 


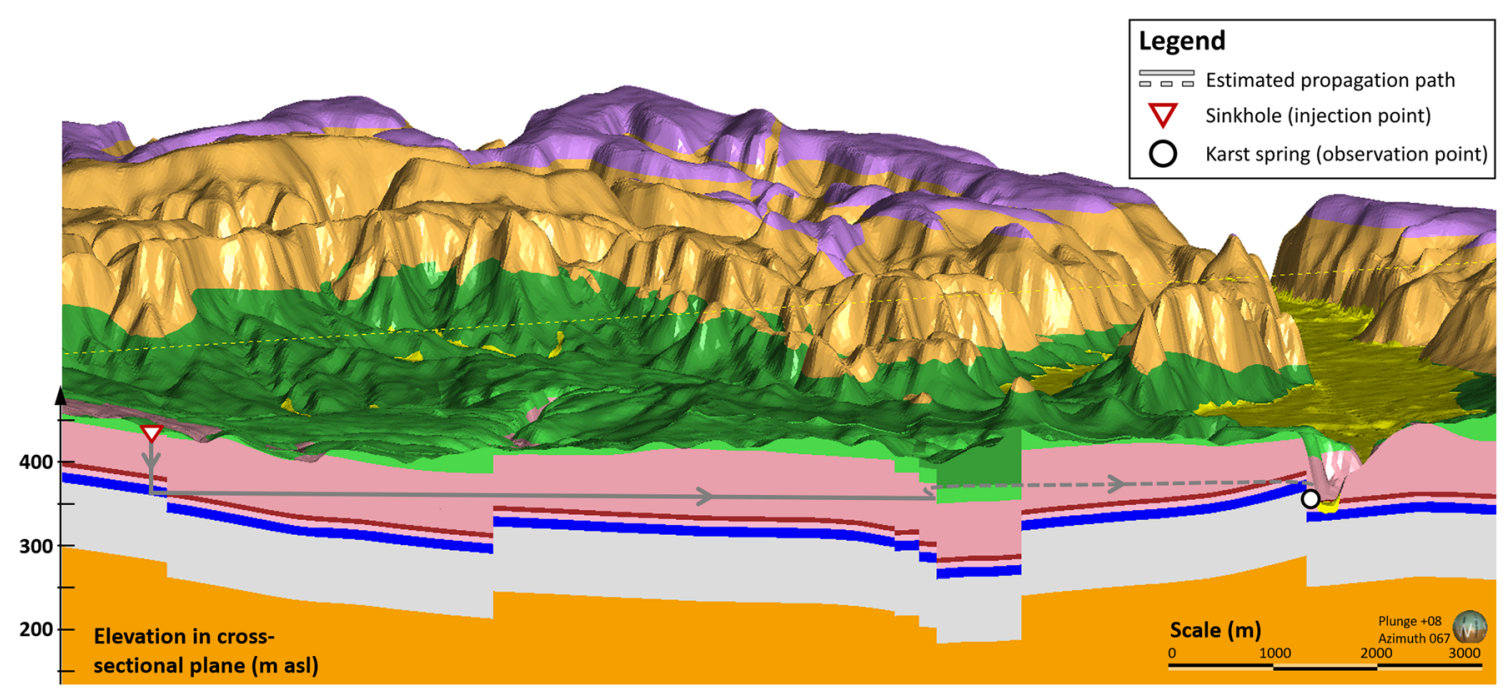

Fig. 10 Estimated path of tracer propagation during the test in 2017 from injection to observation point (Bronnbach spring) with help of the 3-D geological model. The dashed line indicates the circumvention of the Wolfenhausen graben. (For the color code of the geological units see Fig. 8)

properties of a fault core zone may change over time, initially acting as a conduit during deformation, and subsequently as a barrier, if mineral precipitation, clay or even breccia clogs the fault plain (e.g., Caine et al. 1996, Bense et al. 2013).

Though the majority of the tracer tests shows similar results with respect to the observed directions of propagation, they differ with respect to propagation distance and velocity as well as recovery rates. The individual analysis of these data in the context of the specific setting of the tracer test (i.e. aquifer conditions at the location of tracer injection and observation) provides essential information for the parameterization of the numerical model. High values of both velocity and recovery rate, for example, are a clear indication for a hydraulically very effective karst feature linking the injection and observation points. These features need to be explicitly accounted for in the numerical groundwater-flow model if tracer tests are to be reproduced by subsequent particle-tracking simulations.

In the analysis of individual tracer tests, the hydraulic setting along the presumed tracer paths is also important. Some tracer tests showed that the tracers may have migrated also through the confined parts of the Muschelkalk aquifer to the Reusten spring (Fig. 9). Karstification under confined settings generates different morphologies than under unconfined settings. Specific hydrogeologic characteristics under confined conditions (restricted inputs/outputs) reduce positive flowdissolution feedbacks and, consequently, the karstic competition in fracture networks. As a result, more pervasive channeling is likely to be developed under confined settings, i.e. 2-D or 3-D densely packed maze conduits, in contrast to conduitlike morphologies that tend to be broadly spaced and dendritic due to highly competing developments under unconfined conditions. Hence, the values of porosity and specific storage in confined karst systems may be up to one order of magnitude larger than in unconfined settings (e.g., Klimchouk 2006), which should be reflected through larger tracer transit times. Observed tracer migration velocities (based on tracer arrival at the Reusten spring, see GLA 1997), however, suggest an alternative tracer transport path along SE-NW fractures and WSW-ENE synthetic faults (which are connected to WSWENE faults), this way bypassing the confined area. This option of explaining the flow regime is also supported by the fact that the estimated apparent water age in the Poltringen wells is relatively young (Pavlovskiy and Selle 2015). However, a valid clarification is not possible-as in almost all issues concerning the role of fractures, faults, and discrete karst conduits for the flow regime. This particularly applies to local effects, which can hardly be resolved in a catchment-scale model. In contrast, rather regional effects of discrete hydraulically effective features, acting as an internal drainage system that controls the overall water budget, can be better identified and described in a quantitative way as part of the model calibration (see the following).

\section{Numerical groundwater-flow model}

The numerical groundwater-flow model is set up and operated as a steady-state model to provide average groundwater flow data for subsequent particle-tracking simulations. The model follows the single-continuum equivalent porous medium approach where high-permeability features such as karst conduits are simply represented by a series of model cells with extra-high conductivity values. Such models are also referred to as smeared conduit models as they do not attempt to model the detailed geometry of relatively small high-permeability features but try instead to capture the effects of a conduit on 


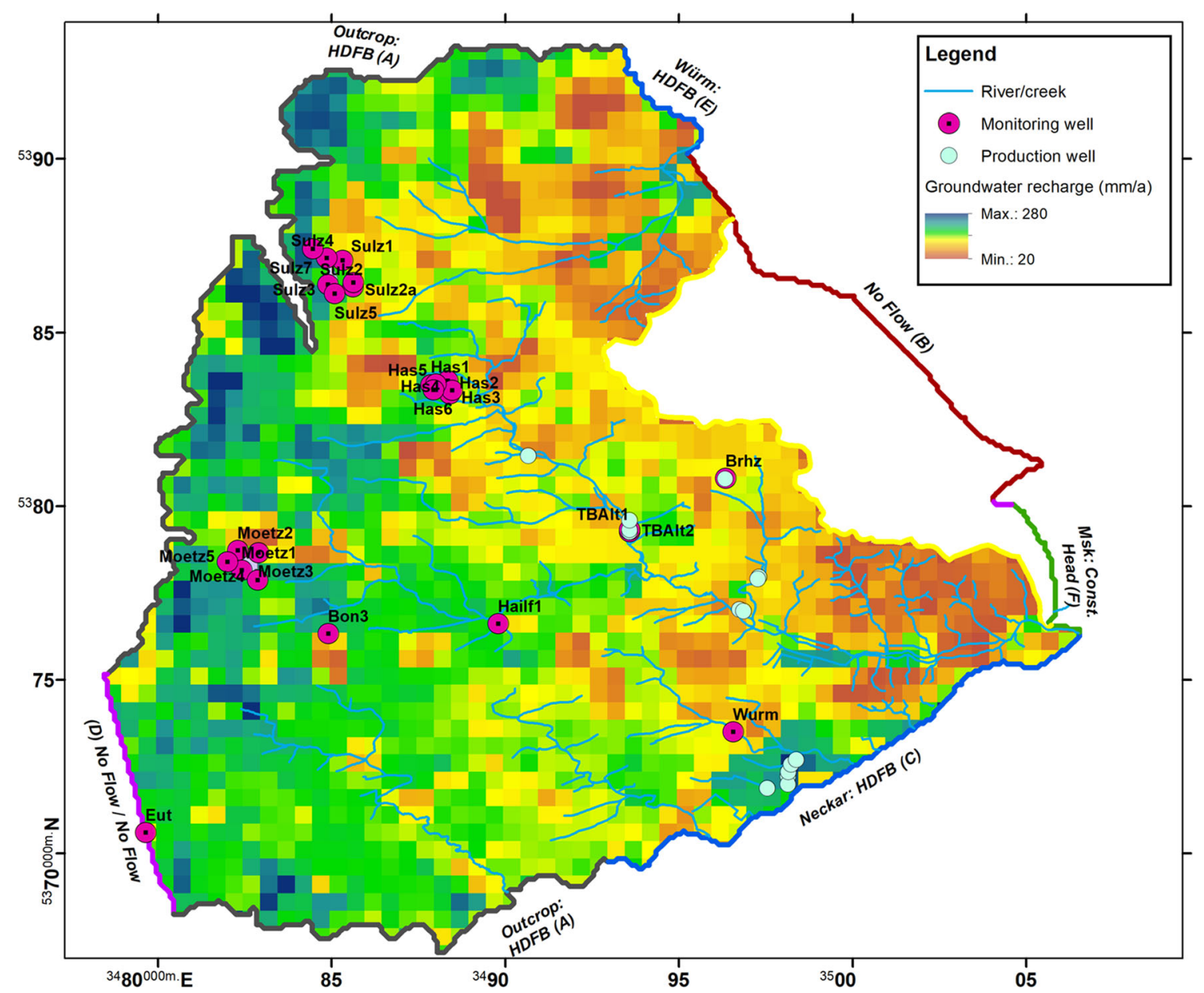

Fig. 11 Model domain, recharge distribution and lateral boundary conditions (HDFB = head-dependent flow boundary)

a much larger computational grid block by assigning effective properties to that grid block (Green et al. 2006).

The model encompasses the entire subsurface catchment of the Ammer River and covers an area of $\sim 470 \mathrm{~km}^{2}$ (Fig. 11). The model boundaries are set as follows: (A) the western and northern boundary, as well as parts of the southern boundary, coincide with the line where the bottom of $\mathrm{mmD}$ crops out, (B) the northeastern boundary follows the Hildrizhausen fault, Bebenhausen graben, and Swabian lineament where the huge offset of layer elevations blocks groundwater flow, (C) the southern boundary runs along the Neckar River, (D) short sections of the model boundary in the southwest and east follow the expected direction of groundwater flow in the Muschelkalk aquifer, (E) in the north the boundary runs along the Würm', and (F) in the east the model boundary connects boundaries B and C. The outcrop boundary (see A) is represented by a head-dependent flux boundary (i.e. 'drain') at the $\mathrm{mmD}$ bottom. The northeastern boundary (B) and the boundaries that follow the assumed groundwater flow direction (D) are defined as no-flow boundaries for both the shallow and the Muschelkalk aquifer. The boundaries along the Neckar and Würm rivers ( $\mathrm{C}$ and $\mathrm{E}$ ) are represented as head-dependent flux boundary (i.e. 'river') for the shallow aquifer and as no-flow boundary for the Muschelkalk aquifer. In the east, a fixed head boundary describes groundwater flow in the Muschelkalk aquifer across the model boundary $(\mathrm{F})$ with the hydraulic head set equal to the level of the Neckar River. Note that the Ammer as well as its tributaries are represented as 'drains' to account for the fact that many stretches of the rivers and creeks are intermittent. With this, any infiltration of surface waters was deliberately neglected, which is, although temporarily observed in the study area, presumably of minor relevance for the steady-state description under average conditions. In the absence of detailed information, the conductance of both drain and river cells were set as high as needed to simulate the assumed good hydraulic contact between groundwater and surface water such that water exchange occurs under small hydraulic potential differences.

Groundwater recharge is set according to a $500 \mathrm{~m} \times 500 \mathrm{~m}$ raster of average rate values (within period 2001 to 2015), provided by LUBW (2016), the state authority for the environment, measurement and conservation in Baden Württemberg that runs the regional soil-water balance model GWN-BWN (see Gudera and Morhard 2015). The recharge 


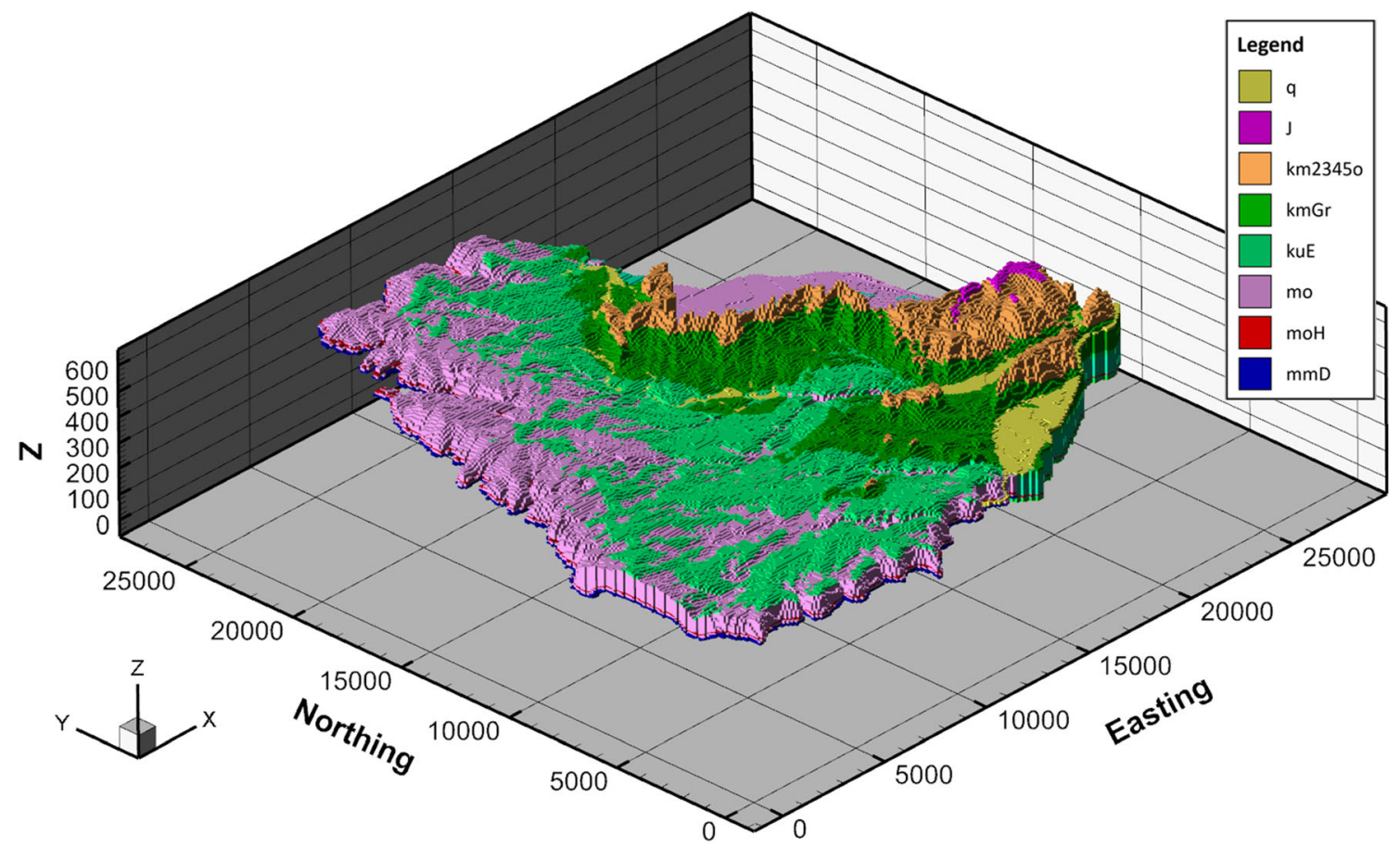

Fig. 12 Geometry of the 3-D finite difference groundwater flow model (active model cells) with regular discretization and assigned parameter zones. View from southwest, local coordinates in meters

rate varies spatially between 20 and $280 \mathrm{~mm} /$ year (Fig. 11). A simplification has been introduced in the northwestern part of the model where groundwater flow presumably takes place only in the shallow, near-surface parts of the subsurface and runs off in the Goldersbach River. In this area, the groundwater flow model considers only the Muschelkalk layers, and the groundwater recharge is set to zero due to the thick overburden.

MODFLOW-NWT (Niswonger et al. 2011) was applied using a regular, horizontally layered grid of $100 \mathrm{~m} \times$ $100 \mathrm{~m} \times 5 \mathrm{~m}$ sized cells (Fig. 12). The model incorporates the upper dolomitic part of the Middle Muschelkalk (Diemel formation, $\mathrm{mmD}$ ), the Upper Muschelkalk (Trochitenkalk formation, moTK, including the Haßmersheimer layers, moH, and the Meissner formation, moM), the Lower Keuper (Erfurt formation, kuE), the gypsum layer in the Middle Keuper (Grabfeld formation, kmGr), further layers of the Middle and Upper Keuper (undifferentiated, km2345o), the Jurassic limestone (J), and the Quaternary layers. The vertical grid resolution of $5 \mathrm{~m}$ is mainly determined by the thickness of the moH and is just sufficient to represent this unit in the model as a continuous layer. Due to the inclination of layers the model domain spans vertically a total number of 132 layers (from $-30 \mathrm{~m}$ to $630 \mathrm{~m}$ asl), each with a different number of active model cells. This regular gridding was chosen because a representation of the stratigraphy with layers of variable thickness showed to be infeasible due to the large number of faults with partly large offsets.

The basic model setup including the zonation, i.e. the assignment of code numbers to all model cells according to stratigraphic layers is done automatically as part of the functionalities of Leapfrog. In this step, the mo and kmGr layers were further differentiated in terms of their anticipated karstification and weathering or leaching status, respectively. The zonation within the Upper Muschelkalk (mo) distinguishes two zones: one zone where karstification of mo is likely, and one zone where, due to an overburden $(\mathrm{kuE}$ and $\mathrm{kmGr}$ ), no relevant karstification of mo is expected (see Fig. S2 of the ESM for an illustration). The Grabfeld formation (kmGr) was differentiated into two zones: one zone where gypsum is expected to have been leached out in the past, and which is assigned to the upper $10-15 \mathrm{~m}$ of $\mathrm{kmGr}$, and one zone where most likely no leaching has taken place (Fig. S3 of the ESM). In total, this hydrostratigraphic zonation yielded 13 different zones (Fig. 3).

The model was calibrated at steady state in the sense of an approximate model calibration. The goal was to achieve a model that reasonably reproduces the hydraulic head measurements at the monitoring wells in the Muschelkalk aquifer (see Fig. 11) and the estimated water balance of the Ammer catchment including parts of its neighboring catchments. As data and properties of the model boundaries were largely fixed (see above), the calibration was done with respect to the spatial distribution of hydraulic conductivity only. The calibration process consisted of two steps that are iteratively run through: (1) estimation of the hydraulic conductivity values of each zone that has been differentiated in advance (as discussed previously), (2) incorporation of high-conductivity cells to mimic discrete karst conduits to 'correct' the model 
Table 1 Hydraulic conductivity values estimated in approximate model calibration

\begin{tabular}{llll}
\hline Formation & Abbreviation & $\begin{array}{l}K_{\text {hor }} \\
{[\mathrm{m} / \mathrm{s}]}\end{array}$ & $\begin{array}{l}\text { Anisotropy ratio } \\
K_{\text {ver: }}: K_{\text {hor }}\end{array}$ \\
\hline Quaternary (Ammer Valley) & q-A & $5.5 \mathrm{E}-04$ & $1: 10$ \\
Quaternary (Neckar Valley) & $\mathrm{q}-\mathrm{N}$ & $1.2 \mathrm{E}-03$ & $1: 10$ \\
Jurassic Limestone & $\mathrm{Ju}$ & $3.0 \mathrm{E}-08$ & $1: 10$ \\
Upper Keuper & $\mathrm{Ko}$ & $5.0 \mathrm{E}-08$ & $1: 10$ \\
Middle Keuper (undifferentiated) & $\mathrm{Km} 2345$ & $5.0 \mathrm{E}-08$ & $1: 10$ \\
Middle Keuper (Grabfeld Formation), unleached & $\mathrm{kmGr}-\mathrm{ul}$ & $5.0 \mathrm{E}-08$ & $1: 10$ \\
Middle Keuper (Grabfeld Formation), leached & $\mathrm{kmGr}-1$ & $8.0 \mathrm{E}-06$ & $1: 1$ \\
Lower Keuper (Erfurt Formation) & $\mathrm{kuE}$ & $1.0 \mathrm{E}-06$ & $1: 10$ \\
Upper Muschelkalk, w/o overburden, karstified & $\mathrm{mo}$ & $1.0 \mathrm{E}-04$ & $1: 1$ \\
Upper Muschelkalk, with overburden (kuE, KmGr), not & $\mathrm{mo}-\mathrm{ov}$ & $2.6 \mathrm{E}-06$ & $1: 1$ \\
$\quad$ karstified & & & \\
Upper Muschelkalk, Haßmersheimer layer & $\mathrm{moH}$ & $1.0 \mathrm{E}-07$ & $1: 1$ \\
Upper Muschelkalk, conduits & $\mathrm{mo-cond}$ & $2.0 \mathrm{E}-01$ & $1: 1$ \\
Middle Muschelkalk & $\mathrm{mmD}$ & $7.0 \mathrm{E}-05$ & $1: 1$ \\
\hline
\end{tabular}

parameterization resulting from step 1. This second step has shown to be necessary to properly model the water balance in the domain, particularly the discharge of the Bronnbach spring. With a pure zonal calibration, no reasonable result could be achieved. Obviously, there is no clear evidence or knowledge about the location of such conduit-like karst features but information about karstification (Fig. 5) and about flow direction from tracer tests (see Figs. 6 and 9) gave a good orientation for reasonable guesses. Particularly, tracer tests suggest that karst conduits are more evolved along antithetic fractures (joints and faults), whose strikes are roughly parallel to the dipping strata. Furthermore, the calibration was supported by particle tracking simulations using MODPATH (Pollock 1994) to visualize catchment areas in the model domain (not shown). This way, both high- $K$ features and zonal $K$ values were estimated. Figure S2 of the ESM shows the
Fig. 13 Results of approximate model calibration

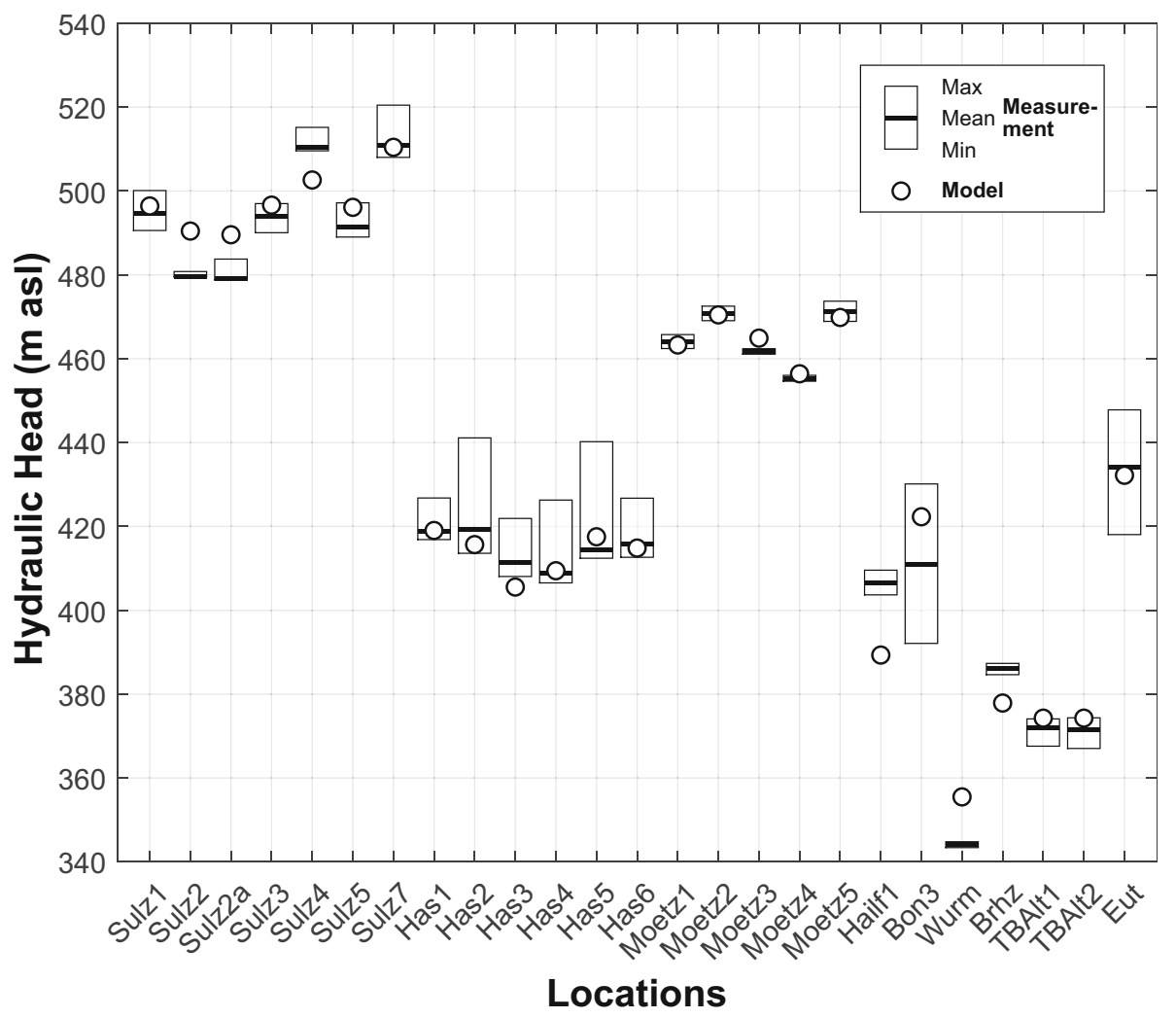


discrete karst features that have been delineated in the calibration process. Estimated zonal $K$ values (Table 1) show appropriate values that are all within the reported ranges (see the preceding). The comparison of modelled and measured hydraulic head values shows a reasonable agreement (Fig. 13) given that no further spatial differentiation of $K$ within the hydrostratigraphic zones has been introduced during the calibration. Local-scale variations, as are reflected by the three monitoring well clusters at the quarries (see Fig. 13: Sulz1 to Sulz7, Has1 to Has6, and Moetz1 to Moetz5), cannot be properly resolved by the model as expected, but regionally the model seems to appropriately describe the hydraulic situation in the Muschelkalk aquifer. The largest deviation $(\sim 17 \mathrm{~m})$ exists at Hailfingen (Hailf1) where, so far, measurements could be made available only for a half-year period in 2019 . The calculated mean ( $406.5 \mathrm{~m}$ asl) may not represent average conditions (note that Villinger (1982) mentioned a value of "390-396 m asl"). At Wurmlingen (Wurm), the deviation is most likely related to the definition of the model boundary in this area. As there is no clear information available about the flow conditions in the Muschelkalk aquifer below and along the Neckar River, a no-flow boundary was set in the Muschelkalk (see the preceding) — assuming that flow is parallel to the Neckar, and groundwater may discharge only across the eastern boundary or to the Neckar after passing through the Erfurt and Grabfeld formations. A likely explanation for the deviation at Breitenholz (Brhz) is the fact that the monitoring well is very close to the groundwater supply well, a situation that cannot be properly described in the coarsely gridded model.
The modeled groundwater flow rates support quite well the presumed hydrological conditions. The mismatch of topographic and groundwater divides (as depicted in Fig. 6) and associated gains and losses are quantified through inter-catchment flow rates (Table 2). For example, about $80 \%$ of the groundwater that is recharged in area with ID 13 , an area that belongs to the topographic catchment of the Ammer, discharges to the Neckar catchment. In contrast, the Ammer catchment gains from neighboring topographic catchments of the Nagold (about $13 \%$ of the budget of the area with ID 15) and the Würm River (about $93 \%$ of the budget of the area with ID 17). Note that intercatchment flow predominantly occurs in those areas that have been delineated based on the tracer tests (IDs 13, 15, 17 , and 35), which confirms the great significance of tracer tests for the understanding and conceptualization of karstic areas also in this study.

The modeled discharge rate of the Bronnbach spring is $41,580 \mathrm{~m}^{3} /$ day $(\sim 480 \mathrm{~L} / \mathrm{s})$, which agrees well with the mean of the rates measured within the period 1984-2019 $(530 \mathrm{~L} / \mathrm{s})$. A similar good agreement was achieved for the Ammer spring and the Herrenberg spring (modeled discharge $=11 \mathrm{~L} / \mathrm{s}$, measured $\sim 15 \mathrm{~L} / \mathrm{s})$ as well as for the Reusten spring $(7 \mathrm{~L} / \mathrm{s}$ vs. $10 \mathrm{~L} / \mathrm{s})$. Furthermore, the steady-state simulation indicates that the tributaries of the Ammer, Würm, and Neckar receive groundwater only locally (Fig. S4 of the ESM).

Based on the modelled steady-state hydraulic head distribution and the derived groundwater-flow field, MODPATH was used to assess the directions of groundwater runoff from the three limestone quarries in the study area in order to

Table 2 Water balance of catchment areas: inter-catchment, input and output flow rates $\left(\mathrm{m}^{3} /\right.$ day). Negative numbers indicate losses/outputs and positive number indicate gains/inputs if the table is read column-wise. $x$ indicates no data. Refer to Fig. 6 for the location and extent of the areas

\begin{tabular}{|c|c|c|c|c|c|c|c|c|}
\hline $\begin{array}{l}\text { Catchment area, } \\
\text { ID }\end{array}$ & $\begin{array}{l}\text { Ammer, } \\
1\end{array}$ & $\begin{array}{l}\text { Neckar, } \\
3\end{array}$ & $\begin{array}{l}\text { Würm, } \\
7\end{array}$ & $\begin{array}{l}\text { Goldersbach, } \\
9\end{array}$ & $\begin{array}{l}\text { Ammer/ Neckar, } \\
13\end{array}$ & $\begin{array}{l}\text { Ammer/ Nagold, } \\
15\end{array}$ & $\begin{array}{l}\text { Ammer/ Würm, } \\
17\end{array}$ & $\begin{array}{l}\text { Neckar/ Nagold, } \\
35\end{array}$ \\
\hline Ammer, 1 & $\mathrm{x}$ & -105 & -398 & 253 & $-4,174$ & $-2,200$ & $-11,636$ & 0 \\
\hline Neckar, 3 & 105 & $\mathrm{x}$ & 0 & -243 & $-19,177$ & 0 & 0 & $-1,192$ \\
\hline Würm, 7 & 398 & 0 & $\mathrm{x}$ & 1,059 & 0 & 174 & -854 & 0 \\
\hline Goldersbach, 9 & -253 & 243 & $-1,059$ & $\mathrm{x}$ & 0 & 0 & 0 & 0 \\
\hline$\underset{13}{\text { Ammer/ Neckar, }}$ & 4,174 & 19,177 & 0 & 0 & $\mathrm{x}$ & -953 & 0 & $-3,658$ \\
\hline $\begin{array}{l}\text { Ammer/ Nagold, } \\
15\end{array}$ & 2,200 & 0 & -174 & 0 & 953 & $\mathrm{x}$ & 5,219 & 246 \\
\hline Ammer/ Würm, 17 & 11,636 & 0 & 854 & 0 & 0 & $-5,219$ & $\mathrm{x}$ & 0 \\
\hline $\begin{array}{l}\text { Neckar/ Nagold, } \\
35\end{array}$ & 0 & 1,192 & 0 & 0 & 3,658 & -246 & 0 & $\mathrm{x}$ \\
\hline Constant head & 0 & 0 & 0 & $-1,294$ & 0 & 0 & 0 & 0 \\
\hline Wells & $-8,520$ & $-3,258$ & 0 & 0 & 0 & 0 & 0 & 0 \\
\hline Recharge & 40,969 & 56,860 & 14,958 & 230 & 18,740 & 17,184 & 7,323 & 10,858 \\
\hline Rivers & $-50,710$ & $-74,109$ & $-14,182$ & -4 & 0 & $-8,763$ & -51 & $-6,259$ \\
\hline Total input & 59,482 & 77,472 & 15,812 & 1,542 & 23,351 & 17,358 & 12,542 & 11,104 \\
\hline Total output & $-59,483$ & $-77,472$ & $-15,813$ & -1541 & $-23,351$ & $-17,381$ & $-12,541$ & $-11,109$ \\
\hline
\end{tabular}


Fig. 14 Modelled hydraulic head distribution in Muschelkalk aquifer and predicted groundwater runoff areas from limestone quarries

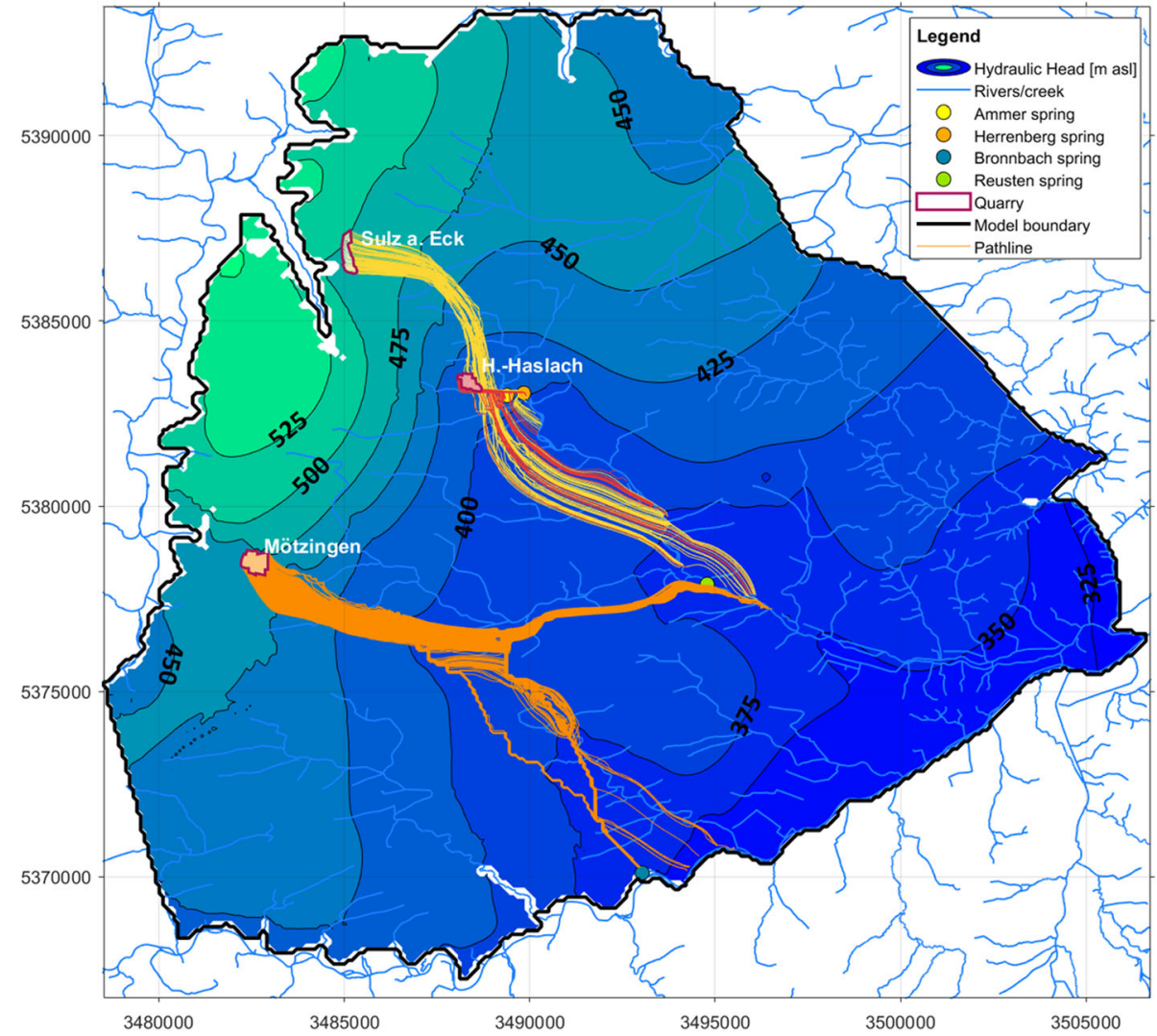

localize receptors that might be at risk in case of accidental spills. The results show that the situation is not clear for any of the quarries (Fig. 14). The runoff of the two quarries near Sulz am Eck and Herrenberg-Haslach may reach the Ammer spring, the Herrenberg spring or the Ammer main stem. For the quarry in Mötzingen, the modelled pathlines identify the Bronnbach spring in the Neckar Valley as the receptor. The model reproduces the findings of the tracer test conducted in this area and confirms the previously estimated path of tracer propagation (Fig. 12). However, the model results also indicate that a runoff towards the Reusten spring and the Ammer main stem cannot be ruled out.

\section{Conclusions and outlook}

In this study, 3-D implicit geological modeling was used to develop a consistent conceptual and geometric model of a karst aquifer system affected by tectonic features. During the model development, using implicit-modeling techniques allowed a fast, automated and straightforward generation of bounding surfaces of geological blocks when additional or modified data in terms of contact points or fault lines shall be taken into account. This is a prerequisite for exploring competing hypotheses in the iterative development and verification of the model, which may be supported through targeted field investigations. Model results must always be critically evaluated, in order to ensure geological realism.

The 3-D geological model allowed the recognition of unmapped subsurface features and provided a better understanding of the aquifer geometry. The acquired understanding of the subsurface structure and flow regime has been essential for the quantitative modeling of groundwater flow and particle-trackingbased risk assessment. Further applications of the model will support individual projects in the collaborative research center (CRC) CAMPOS (University of Tübingen 2020).

Unavoidably, there is insufficient knowledge about the inherently complex organization of hydraulically relevant features in the Middle Triassic karst aquifer. Hence, the presented groundwater model is obviously an approximation, but, thanks to the very good data bases (including an accurate and highly resolved 3-D geological model, the results of a comparatively large number of tracer tests and a reasonably large number of hydraulic head measurements), it was possible to show that the groundwater model represents the measured water regime quite well. A single-continuum equivalent porous medium model (EPM) was employed, which is the simplest approach to incorporate conduits and the one that can be most readily applied in case studies (e.g., Green et al. 2006). While this study and others (see, e.g., Worthington 2009) could show that this approach is useful to simulate karst systems in a steady-state mode to address problems involving annual or monthly average hydrologic 
conditions, EPM models likely cannot mimic the dynamic behavior of the karst system in simulations of, e.g., storm events, when non-laminar, i.e. turbulent flow, in conduits affects discharge (Kuniansky et al. 2016). These issues of transient simulations will need to be examined in future studies including comparisons of the EPM model with double-porosity models (i.e. dual-continuum equivalent models) and coupled continuum pipe-flow models (see Saller et al. (2013) for an example). Both model types are implemented in MODFLOW-CFP (Shoemaker et al. 2008). Note that both the double-porosity and the coupled continuum pipe-flow models require additional parameters to characterize the flow in the conduits, which will complicate model calibration. These parameters include, depending on the model, critical Reynolds numbers, mean void diameter, equivalent porosity or roughness, diameter, and tortuosity, and an exchange coefficient for the interaction between the conduits and matrix.

Funding Open Access funding provided by Projekt DEAL. This work was supported by the Collaborative Research Center 1253 CAMPOS, funded by the German Research Foundation (DFG, Grant Agreement SFB 1253/1 2017) as well as by the consortium of the project "Umweltgerechte Gesteinsgewinnung in Wasserschutzgebieten"-Industrieverband Steine und Erden Baden-Württemberg e.V. (ISTE), Zweckverband AmmertalSchönbuchgruppe (ASG), Regierungspräsidium Freiburg - Landesamt für Geologie, Rohstoffe und Bergbau (LGRB), and Landesanstalt für Umwelt Baden-Württemberg (LUBW).

Open Access This article is licensed under a Creative Commons Attribution 4.0 International License, which permits use, sharing, adaptation, distribution and reproduction in any medium or format, as long as you give appropriate credit to the original author(s) and the source, provide a link to the Creative Commons licence, and indicate if changes were made. The images or other third party material in this article are included in the article's Creative Commons licence, unless indicated otherwise in a credit line to the material. If material is not included in the article's Creative Commons licence and your intended use is not permitted by statutory regulation or exceeds the permitted use, you will need to obtain permission directly from the copyright holder. To view a copy of this licence, visit http://creativecommons.org/licenses/by/4.0/.

\section{References}

Agar SN, Geiger S (2015) Fundamental controls on fluid flow in carbonates: current workflows to emerging technologies. In: Agar S, Geiger S (eds) Current workflows to emerging technologies, geological society special publication. Geological Society of London, London, pp 1-59. https://doi.org/10.1144/SP406.18

ARANZ Geo Limited (2016) Leapfrog ${ }^{\circledR}$ Geo 3.1 users manual and custom training. ARANZ Geo, Christchurch, New Zealand

Alcaraz S, Lane R, Spragg K, Milicich, S, Sepulveda F, Bignall G (2011) 3D geological modelling using new Leapfrog geothermal software. In: Proceedings, Thirty-sixth workshop on geothermal reservoir engineering Stanford University, Stanford, California, January 31February 2, 2011, SGP-TR-191

Bense VF, Gleesonb T, Loveless S, Bour O, Scibek J (2013) Fault zone hydrogeology. Earth Sci Rev 127:171-192. https://doi.org/10.1016/ j.earscirev.2013.09.008
Benson RC, Yuhr LB (2016) Site characterization in karst and pseudokarst terraines: practical strategies and hydrologists and geologists. Springer, Dordrecht, The Netherlands, 421 pp. https://doi. org/10.1007/978-94-017-9924-9

Birch C (2014) New systems for geological modelling: black box or best practice? J S Afr Inst Min Metall [online] 114(12):993-1000

Borghi A, Renard P, Courrioux G (2015) Generation of 3D spatially variable anisotropy for groundwater flow simulations. Groundwater 53(6):955-958. https://doi.org/10.1111/gwat.12295

Borghi A, Renard P, Cornaton F (2016) Can one identify karst conduit networks geometry and properties from hydraulic and tracer test data? Adv Water Res 90:99-115. https://doi.org/10.1016/j. advwatres.2016.02.009

Bredehoeft J (2005) The conceptualization model problem-surprise. Hydrogeol J 13(1):37-46. https://doi.org/10.1007/s10040-0040430-5

Burs D, Bruckmann J, Rude TR (2016) Developing a structural and conceptual model of a tectonically limited karst aquifer: a hydrogeological study of the Hastenrather Graben near Aachen, Germany. Environ Earth Sci 75:1253. https://doi.org/10.1007/ s12665-016-6039-x

Butscher C, Huggenberger P (2008) Intrinsic vulnerability assessment in karst areas: a numerical modeling approach. Water Resour Res 44(3):W03408. https://doi.org/10.1029/2007WR006277

Caine JS, Evans JP, Forster CB (1996) Fault zone architecture and permeability structure. Geology 24(11):1025-1028. https://doi.org/10. 1130/0091-7613(1996)024<1025:FZAAPS >2.3.CO;2

Calcagno P, Chilès JP, Courriouxa G, Guillena A (2008) Geological modelling from field data and geological knowledge: part I. modelling method coupling 3D potential-field interpolation and geological rules. Phys Earth Planet Inter 171:147-157. https://doi.org/10.1016/ j.pepi.2008.06.013

Caumon G, Gray G, Antoine C, Titeux MO (2013) Three-dimensional implicit stratigraphic model building from remote sensing data on tetrahedral meshes: theory and application to a regional model of La Popa Basin, NE Mexico. IEEE Trans Geosci Remote Sens 51(3): 1613-1621. https://doi.org/10.1109/TGRS.2012.2207727

Chen Z, Goldscheider N (2014) Modeling spatially and temporally varied hydraulic behavior of a folded karst system with dominant conduit drainage at catchment scale, Hochifen-Gottesacker, Alps. J Hydrol 514:41-52. https://doi.org/10.1016/j.jhydrol.2014.04.005

Cherpeau N, Caumon G, Levy B (2010) Stochastic simulations of fault networks in 3D structural modeling. C R Geosci 342(9):687-694. https://doi.org/10.1016/j.crte.2010.04.008

Collon P, Steckiewicz-Laurent W, Pellerin J, Laurent G, Caumon G, Reichart G, Vaute L (2015) 3D geomodelling combining implicit surfaces and Voronoi-based remeshing: a case study in the Lorraine Coal Basin (France). Comput Geosci 77:29-43. https://doi.org/10. 1016/j.cageo.2015.01.009

Cowan EJ, Beatson RK, Ross HJ, Fright WR, McLennan TJ, Evans TR, Carr JC, Lane RG, Bright DV, Gillman AJ, Oshust PA, Titley M (2003) Practical implicit geological modelling. Fifth International Mining Geology Conference, Bendigo (Vic), Australia, AusIMM Publication Series 8/2003, AUS IMM, Carlton, Australia, pp 89-99

Cowan EJ, Lane RG, Ross HJ (2004) Leapfrog's implicit drawing tool: a new way of drawing geological objects of any shape rapidly in 3D. In: Proceedings of the Australian institute of geoscientists mining geology, Brisbane, Australia, 21 October 2014, pp 23-25

Cox ME, James A, Hawke A, Raiber M (2013) Groundwater visualisation system (GVS): a software framework for integrated display and interrogation of conceptual hydrogeological models, data and timeseries animation. J Hydrol 491:56-72. https://doi.org/10.1016/j. jhydrol.2013.03.023

de Kemp EA (1999) Visualization of complex geological structures using 3-D Bézier construction tools. Comput Geosci 25(5):581-597. https://doi.org/10.1016/S0098-3004(98)00159-9 
de la Varga M, Schaaf A, Wellmann F (2019) GemPy 1.0: open-source stochastic geological modeling and inversion. Geosci Model Dev 12(1):1-32. https://doi.org/10.5194/gmd-12-1-2019

de Rooij R, Perrochet P, Graham W (2013) From rainfall to spring discharge: coupling conduit flow, subsurface matrix flow and surface flow in karst systems using a discrete-continuum model. Adv Wat Res 61:29-41. https://doi.org/10.1016/j.advwatres.2013.08.009

Enemark T, Peeters LJ, Mallants D, Batelaan O (2019) Hydrogeological conceptual model building and testing: a review. J Hydrol 569:310 329. https://doi.org/10.1016/j.jhydrol.2018.12.007

Fogg GE (1986) Groundwater flow and sand body interconnectedness in a thick, multiple-aquifer system. Water Resour Res 22(5):679. https://doi.org/10.1029/WR022i005p00679

Ford DC (2003) Perspectives in karst hydrogeology and cavern genesis. In: Speleogenesis and evolution of karst aquifers. J Hydrol 1(1):1-12

Ghasemizadeh R, Hellweger F, Butscher C, Padilla I, Vesper D, Field M, Alshawabkeh A (2012) Review: Groundwater flow and transport modeling of karst aquifers, with particular reference to the north coast limestone aquifer system of Puerto Rico. Hydrogeol J 20(8): 1441-1461. https://doi.org/10.1007/s10040-012-0897-4

Ghasemizadeh R, Yu X, Butscher C, Hellweger F, Padilla I, Alshawabkeh A (2015) Equivalent porous media (EPM) simulation of groundwater hydraulics and contaminant transport in karst aquifers. PLoS One 10(9):121. https://doi.org/10.1371/journal.pone.0138954

Gjoystdal H, Reinhardsen JE, Astebol K (1985) Computer representation of 3-D geological structures using a new "solid modeling" technique. Geophys Prospect 33(8):1195-1211. https://doi.org/10. 1111/j.1365-2478.1985.tb01359.x

GLA (1966) Geologische Karte 1:25.000 von Baden-Württemberg, Blatt 7419 Herrenberg [Geological map of the State of BadenWürttemberg, sheet 7419 Herrenberg]. Geologisches Landesamt Baden-Württemberg, Stuttgart, Germany

GLA (1986) Geologische Karte 1:25.000 von Baden-Württemberg, blatt 7320 Böblingen [Geological map of the state of BadenWürttemberg, sheet 7320 Böblingen]. Geologisches Landesamt Baden-Württemberg, Stuttgart, Germany

GLA (1989) Geologische Karte 1:25.000 von Baden-Württemberg, blatt 7418 Nagold [Geological map of the state of Baden-Württemberg, sheet 7418 Nagold]. Geologisches Landesamt Baden-Württemberg, Stuttgart, Germany

GLA (1992) Geologische Karte 1:25.000 von Baden-Wüttemberg, blatt 7319 Gärtringen [Geological map of the state of BadenWürttemberg, sheet 7319 Gärtringen]. Geologisches Landesamt Baden-Württemberg, Stuttgart, Germany

GLA (1994a) Geologische Karte 1:25.000 von Baden-Württemberg, blatt 7518 Horb [Geological map of the state of Baden-Württemberg, sheet 7518 Horb]. Geologisches Landesamt Baden-Württemberg, Stuttgart, Germany

GLA (1994b) Geologische Karte 1:25.000 von Baden-Württemberg, Blatt 7519 Rottenburg [Geological map of the state of BadenWürttemberg, sheet 7519 Rottenburg]. Geologisches Landesamt Baden-Württemberg, Stuttgart, Germany

GLA (1994c) Geologische Karte 1:25.000 von Baden-Württemberg, Blatt 7520 Mössingen [Geological map of the State of BadenWürttemberg, sheet 7520 Rottenburg]. Geologisches Landesamt Baden-Württemberg, Stuttgart, Germany

GLA (1997) Hydrogeologisches Folgegutachten zum Wasserschutzgebiet für die Fassungen des ZV Ammertal Schönbuchgruppe und der Stadt Herrenberg: Ergebnisse des Markierungsversuchs Nr. 1092 [Hydrogeological report on the water protection zone of the productions wells from Ammertal Schönbuchgruppe and the city of Herrenberg: results of tracer test no. 1092]. Geologisches Landesamt BadenWürttemberg, Stuttgart, Germany

Goncalves IG, Kumaira S, Guadagnin F (2017) A machine learning approach to the potential-field method for implicit modeling of geological structures. Comput Geosci 103:173-182. https://doi. org/10.1016/j.cageo.2017.03.015

Green RT, Painter SL, Sun A, Worthington SRH (2006) Groundwater contamination in karst terranes. Water Air Soil Pollut: Focus 6:157170. https://doi.org/10.1007/s11267-005-9004-3

Gudera T, Morhard A (2015) Hoch aufgelöste Modellierung des Bodenwasserhaushalts und der Grundwasserneubildung mit GWN-BW [High-resolution modelling of soil water balance and groundwater recharge using GWN-BW]. Hydrol Wasserbewirtsch 59(5):205-216. https://doi.org/10.5675/HyWa_2015,5_1

Guo J, Zhou W, Wu L (2016) Implicit three-dimensional geo-modellingbased on HRBF surface. In: Int. arch. Photogramm. Remote Sens Spatial Inf Sci XLII-2/W2:63-66. https://doi.org/10.5194/isprsarchives-XLII-2-W2-63-2016

Harreß HM (1973) Hydrogeologische Untersuchungen im Oberen Gäu [Hydrogeological investigations within the area 'Oberes Gäu']. PhD Thesis, University of Tübingen, Germany

Hartmann A, Goldscheider N, Wagener T, Lange J, Weiler M (2014) Karst water resources in a changing world: review of hydrological modeling approaches. Rev Geophys 52:218-242. https://doi.org/10. 1002/2013RG000443

Hassen I, Gibson H, Hamzaoui-Azaza F, Negro F, Rachid K, Bouhlila R (2016) 3D geological modeling of the Kasserine aquifer system, central Tunisia: new insights into aquifer-geometry and interconnections for a better assessment of groundwater resources. J Hydrol 539:223-236. https://doi.org/10.1016/j.jhydrol.2016.05.034

Hillier MJ, Schetselaar EM, de Kemp EA, Perron G (2014) Threedimensional modelling of geological surfaces using generalized interpolation with radial basis functions. Math Geosci 46(8):931-953. https://doi.org/10.1007/s11004-014-9554-x

Hillier MJ, de Kemp E, Schetselaar E (2016) Implicitly modelled stratigraphic surfaces using generalized interpolation. Proceedings of the International Conference on Numerical Analysis and Applied Mathematics 2015 (Icnaam-2015) 1738. https://doi.org/10.1063/1. 4951819

Hornung J, Aigner T (1999) Reservoir- and aquifer characterisation of fluvial architectural elements: Stubensandstein, upper Triassic, South-West Germany. Sediment Geol 129:215-280. https://doi. org/10.1016/S0037-0738(99)00103-7

Hosseini SM, Ataie-Ashtiani B, Simmons CT (2017) Spring hydrograph simulation of karstic aquifers: impacts of variable recharge area, intermediate storage and memory effects. J Hydrol 552:225-240. https://doi.org/10.1016/j.jhydrol.2017.06.018

Illies JH, Baumann H, Hoffers B (1981) Stress pattern and strain release in the Alpine foreland. Tectonophysics 71(1-4):157-172. https:// doi.org/10.1016/0040-1951(81)90059-7

Jeannin P-Y (2001) Modeling flow in phreatic and epiphreatic karst conduits in the Hölloch Cave (Muotatal, Switzerland). Water Resour Res 37(2):191-200. https://doi.org/10.1029/2000WR900257

Jukić D, Denić-Jukić V (2009) Groundwater balance estimation in karst by using a conceptual rainfall-runoff model. J Hydrol 373:302-315. https://doi.org/10.1016/j.jhydrol.2009.04.035

Junginger T (2019) Determination and quantification of groundwater inflow in a complex river system: a comparison between geochemical and anthropogenic tracers. MSc Thesis, University of Tübingen, Germany

Kalhor K, Ghasemizadeh R, Rajic L, Alshawabkeh A (2019) Assessment of groundwater quality and remediation in karst aquifers: a review. Groundw Sustain Develop 8:104-121. https://doi.org/10.1016/j. gsd.2018.10.004

Király L (1979) Remarques sur la simulation des failles et du réseau karstique par éléments finis dans les modèles d'écoulement [Comments on the simulation of faults and the karstic network by finite elements in models of flow]. Bull Centre Hydrogéol 3:155-167

Klimchouk A (2006) Unconfined versus confined speleogenetic settings: variations of solution porosity. Int J Speleol 35(1):19-24. https://doi. org/10.5038/1827-806X.35.1.3 
Kovács A, Sauter M (2007) Modelling karst hydrodynamics. In: Goldscheider N, Drew D (eds) Methods in karst hydrogeology. IAH International Contributions to Hydrogeology, vol 26, chap 10. Taylor and Francis, London, $22 \mathrm{pp}$

Kuniansky EL (2016) Simulating groundwater flow in karst aquifers with distributed parameter models: comparison of porous-equivalent media and hybrid flow approaches. US Geol Surv Sci Invest Rep 20165116 . https://doi.org/10.3133/sir201665116

Lajaunie C, Courrioux G, Manuel L (1997) Foliation fields and 3D cartography in geology: principles of a method based on potential interpolation. Math Geol 29(4):571-584. https://doi.org/10.1007/ BF02775087

Laurent G, Ailleres L, Grose L, Caumon G, Jessell M, Armit R (2016) Implicit modeling of folds and overprinting deformation. Earth Planet Sci Lett 456:26-38. https://doi.org/10.1016/j.epsl.2016.09.040

Lessoff SC, Schneidewind U, Leven C, Blum P, Dietrich P, Dagan G (2010) Spatial characterization of the hydraulic conductivity using direct-push injection logging. Water Resour Res 46(3):W12502. https://doi.org/10.1029/2009WR008949

LGL (2012) Digitales Geländemodell (DGM) von Baden-Württemberg Gitterweite 10m - DGM10 [Digital terrain model of the state of Baden-Württemberg]. Landesamt für Geoinformation und Landentwicklung Baden-Württemberg. https://www.lgl-bw.de/. Accessed August 14, 2019

LGRB (1996) Geologische Karte von Baden-Württemberg 1:25.000, Blatt 7318 Wildberg [Geological map of the State of BadenWürttemberg, sheet 7318 Wildberg]. Landesamt für Geologie, Rohstoffe und Bergbau Baden-Württemberg, Regierungspräsidium Freiburg, Stuttgart, Germany

LGRB (1998) Geologische Übersichtskarte von Baden-Württemberg 1: 300,000 (GÜ 300) [Geological map of the state of BadenWürttemberg 1:300,000]. Landesamt für Geologie, Rohstoffe und Bergbau Baden-Württemberg. http://maps.lgrb-bw.de/. Accessed August 14, 2019)

LGRB (1999) Hydrogeologische Untersuchungen im Neckartal, Raum Tübingen ([Hydrogeological investigations in the Neckar Valley, Tübingen area]. Bearbeiter: Selg. Landesamt für Geologie, Rohstoffe und Bergbau Baden-Württemberg, Stand 17, September 1999, LGRB, Stuttgart, Germany

LGRB (2005) Geologische Karte von Baden-Württemberg 1:25.000. Blatt 7420 Tübingen [Geological map of the State of BadenWürttemberg, sheet 7420 Tübingen). Landesamt für Geologie, Rohstoffe und Bergbau Baden-Württemberg, Regierungspräsidium Freiburg, LGRB, Stuttgart, Germany

LGRB (2012) Geologische Karte von Baden-Württemberg [Geological map of the state of Baden-Württemberg]. 1:50,000 (GeoLa), blattschnittfreie Vektordaten (ESRI Shapefile Format), UTM-32N, ETRS1989 (EPSG: 25832), LGRB, Stuttgart, Germany

LGRB (2014) Ingenieurgeologische Gefahrenhinweiskarte für BadenWürttemberg (IGHK50) 1:50,000 [Geological hazard map of the state of Baden-Württemberg]. LGRB, Stuttgart, Germany. http:// geogefahren.lgrb-bw.de/. Accessed August 08, 2019)

LGRB (2020) Kartenviewer: Layer Aufschlussdatenbank/Bohrdatenbank (ADB) [Map viewer: Layer Drillings and Exposures]. Landesamt für Geologie, Rohstoffe und Bergbau Baden-Württemberg, Regierungspräsidium Freiburg, of Baden-Württemberg, LGRB, Stuttgart, Germany. http://maps.lgrb-bw.de. Accessed June 30, 2020

Liedl R, Sauter M, Hückinghaus D, Clemens T, Teutsch G (2003) Simulation of the development of karst aquifers using a coupled continuum pipe flow model. Water Resour Res 39(3). https://doi. org/10.1029/2001WR001206

Lombardi S, Voltattorni N (2010) Rn, He and $\mathrm{CO}_{2}$ soil gas geochemistry for the study of active and inactive faults. Appl Geochem 25:12061220. https://doi.org/10.1016/j.apgeochem.2010.05.006

LUBW (2016) Sickerwasser- und Grundwasserneubildungraten im Untersuchungsgebiet [Infiltration and recharge rates within the area of interest]. Landesanstalt für Umwelt, Messungen und Naturschutz Baden-Württemberg, Stuttgart, Germany.

Martin R, Boisvert JB (2017) Iterative refinement of implicit boundary models for improved geological feature reproduction. Comput Geosci 109:1-15. https://doi.org/10.1016/j.euromechflu.2015.03.003

Martin PJ, Frind EG (1998) Modeling a complex multi-aquifer system: the Waterloo moraine. Ground Water 36:679-690. https://oi.org/ 10.1111/j.1745-6584.1998.tb02843.x

Martinez JL, Raiber M, Cendón DI (2017) Using 3-D geological modelling and geochemical mixing models to characterise alluvial aquifer recharge sources in the upper Condamine River catchment, Queensland, Australia. Sci Total Environ 574:1-18. https://doi. org/10.1016/j.scitotenv.2016.09.029

Milicich SD, Bardsley C, Bignall G, Wilson CJN (2014) 3-D interpretative modelling applied to the geology of the Kawerau geothermal system, Taupo volcanic zone, New Zealand. Geothermics 51:344 350. https://doi.org/10.1016/j.geothermics.2014.03.002

Moya CE, Raiber M, Cox ME (2014) Three-dimensional geological modelling of the Galilee and central Eromanga basins, Australia: new insights into aquifer/aquitard geometry and potential influence of faults on inter-connectivity. J Hydrol 2:119-139. https://doi.org/ 10.1016/j.ejrh.2014.08.007

Niswonger RG, Panday S, Ibaraki M (2011) MODFLOW-NWT, a Newton formulation for MODFLOW-2005: US Geological Survey Techniques and Methods 6-A37, USGS, Reston, VA, 44 pp

Pakyuz-Charrier E, Lindsay M, Ogarko V, Giraud J, Jessell M (2017) Monte Carlo simulation for uncertainty estimation on structural data in implicit 3-D geological modeling: a guide for disturbance distribution selection and parameterization. Solid Earth 9(2):385-402. https://doi.org/10.5194/se-9-385-2018

Pakyuz-Charrier E, Lindsay M, Ogarko V, Giraud J, Jessell M (2018) Monte Carlo simulation for uncertainty estimation on structural data in implicit 3-D geological modeling, a guide for disturbance distribution selection and parameterization. Solid Earth 9(2):385-402

Pavlovskiy I, Selle B (2015) Integrating hydrogeochemical, hydrogeological, and environmental tracer data to understand groundwater flow for a karstified aquifer system. Groundwater 53: 156-165. https://doi.org/10.1111/gwat.12262

Perrin J, Luetscher M (2008) Inference of the structure of karst conduits using quantitative tracer tests and geological information: example of the Swiss Jura. Hydrogeol J 16:951. https://doi.org/10.1007/ s10040-008-0281-6

Perrin M, Zhu B, Rainaud J-F, Schneider S (2005) Knowledge-driven applications for geological modeling. J Petroleum Sci Eng 47(1-2): 89-104. https://doi.org/10.1016/j.petrol.2004.11.010

Petrovic A (2016) Complexity of carbonate ramp reservoirs: regional sedimentological evaluation and modeling of a Coquina shoal outcrop analog (Upper Muschelkalk, Triassic, SW Germany). PhD Thesis, University of Tübingen, Germany

Philippon M, de Veslud CL, Gueydan F, Brun JP, Caumon G (2015) 3D geometrical modelling of post-foliation deformations in metamorphic terrains (Syros, Cyclades, Greece). J Struct Geol 78:134-148. https://doi.org/10.1016/j.jsg.2015.07.002

Plümacher J (1999) Kalibrierung eines regionalen Grundwasserströmungsmodells mit Hilfe von Umweltisotopeninformation [Calibration of a regional groundwater model by support of environmental isotopes data]. PhD Thesis, ETH Zürich, Switzerland

Plümacher J, Ufrecht W (2000) Erkundung der regionalen Grundwasserströmung im Muschelkalk Mittelwürttembergs mit stabilen Umweltisotopen [Investigation of regional groundwater flow within the Muschelkalk in central Württemberg with the help of environmental isotopes]. Grundwasser 5(1):3-8

Pollock DW (1994) User's guide for MODPATH/MODPATH-PLOT, version 3: a particle tracking post-processing package for 
MODFLOW, the U.S. Geological Survey finite-difference groundwater flow model. US Geol Surv Open File Rep 94-464, 248 pp

Raiber M, Webb JA, Cendón DI, White PA, Jacobsen GE (2015) Environmental isotopes meet 3-D geological modelling: conceptualising recharge and structurally-controlled aquifer connectivity in the basalt plains of South-Western Victoria, Australia. J Hydrol 527:262-280. https://doi.org/10.1016/j.jhydrol.2015.04.053

Raiber M, Lewis S, Cendón DI, Cui T, Cox ME, Gilfedder M, Rassam DW (2019) Significance of the connection between bedrock, alluvium and streams: a spatial and temporal hydrogeological and hydrogeochemical assessment from Queensland, Australia. J Hydrol 569:666-684. https://doi.org/10.1016/j.jhydrol.2018.12.020

Reuther C-D (1973) Schichtlagerung und Tektonik im Oberen Gäu (westl. Tübingen) [Layering and tectonics in the area "Oberes Gäu" (west of the city of Tübingen)]. Diploma Thesis, Institute for Geology and Paleontology, University of Tübingen, Germany

Robins NS, Rutter HK, Dumpleton S, Peach DW (2005) The role of 3-D visualisation as an analytical tool preparatory to numerical modelling. J Hydrol 301(1-4):287-295. https://doi.org/10.1016/j.jhydrol. 2004.05.004

Ross M, Parent M, Lefebvre R (2005) 3-D geologic framework models for regional hydrogeology and land-use management: a case study from a Quaternary basin of southwestern Quebec, Canada. Hydrogeol J 13:690. https://doi.org/10.1007/s10040-004-0365-x

Saller SP, Ronayne MJ, Long AJ (2013) Comparison of a karst groundwater model with and without discrete conduit flow. Hydrogeol J 21:1555-1566. https://doi.org/10.1007/s10040-013-1036-6

Sauter M (1993) Double porosity models in karstified limestone aquifers: field validation and data provision. In: Günay G, Johnson AI, Back W (eds) Hydrogeological processes in karst terranes. Proceedings of the International Symposium and Field Seminar, Antalya, Turkey, October 7-17, 1990. IAHS Publication no. 207, International Association of Hydrological Sciences, Wallingford, UK, pp 261279

Schlosser T, Schmidt M, Schneider M, Vermeer P (2007) Potenzial der Tunnelbaustrecke des Bahnprojektes Stuttgart 21 zur Wärme- und Kältenutzung [Potential of the tunnel construction line of the Stuttgart 21 railway project for heat and cold use]. Institut für Gebäude Energetik (IGE), Institut für Geotechnik (IGS), University of Stuttgart, Stuttgart, Germany

Schütze C, Vienken T, Werban U, Dietrich P, Finizola A, Leven C (2012) Joint application of geophysical methods and direct push-soil gas surveys for the improved delineation of buried fault zones. J Appl Geophys 82:129-136. https://doi.org/10.1016/j.jappgeo.2012.03. 002

Schwarz H-U, Kilfitt F-W (2008) Confluence and intersection of interacting conjugate faults: a new concept based on analogue experiments. J Struct Geol 30:1126-1137. https://doi.org/10.1016/j. jsg.2008.05.005

Selle B, Rink K, Kolditz O (2013) Recharge and discharge controls on groundwater travel times and flow paths to production wells for the Ammer catchment in SW Germany. Environ Earth Sci 69:443-452. https://doi.org/10.1007/s12665-013-2333-z

Shoemaker WB, Kuniansky EL, Birk S, Bauer S, Swain ED (2008) Documentation of a conduit flow process (CFP) for MODFLOW-
2005. US Geological Survey Techniques and Methods, Book 6, Chapter A24, USGS, Reston, VA, $50 \mathrm{pp}$

Tritz S, Guinot V, Jourde H (2011) Modelling the behaviour of a karst system catchment using non-linear hysteretic conceptual model. J Hydrol 397:250-262. https://doi.org/10.1016/j.jhydrol.2010.12.001

Riesner M, Durand-Riard P, Hubbard J, Plesch A, Shaw JH (2017) Building objective 3D fault representations in active tectonic settings. Seismological Res Lett 88(3):831-839. https://doi.org/10. $1785 / 0220160192$

Ufrecht W (2006) Hydrogeologie des Stuttgarter Mineralwassersystems [Hydrogeology of the mineral water system of the city of Stuttgart]. Schriftenreihe des Amtes für Umweltschutz, Heft 3/2006, Stuttgart, Germany, pp 19-48

Ufrecht W (2017) Zur Hydrogeologie veränderlich fester Gesteine mit Sulfatgestein, Beispiel Gipskeuper (Trias, Grabfeld-formation) [The hydrogeology of sulfate-bearing soft rocks: a case studyGipskeuper (Triassic, Grabfeld-formation)]. Grundwasser 22:197208. https://doi.org/10.1007/s00767-017-0362-3

University of Tübingen (2020) SFB 1253 CAMPIOS - Catchments as Reactors: Schadstoffumsatz auf der Landschaftsskala (CRC CAMPOS - catchments as reactors: pollutant turnover at catchment scale]. Erberhard Karls Universität Tübingen. https://uni-tuebingen. $\mathrm{de} / \mathrm{en} / \mathrm{research} / \mathrm{core}-$ research/collaborative-research-centers/crc1253/. Accessed June 30, 2020

Villinger E (1982) Grundwasserbilanzen im Karstaquifer des Oberen Muschelkalks im Oberen Gäu (Baden-Württemberg) [Groundwater balances in the karst aquifer of the Upper Muschelkalk in the "Oberes Gäu" area]. Geologisches Jahrbuch, Reihe C, Heft 32, German Geological Survey BGR, Hannover, Germany

Vollgger SA, Cruden AR, Ailleres L, Cowan EJ (2015) Regional dome evolution and its control on ore-grade distribution: insights from $3 \mathrm{D}$ implicit modelling of the Navachab gold deposit. Namib Ore Geolo Rev 69:268-284. https://doi.org/10.1016/j.oregeorev.2015.02.020

Waltham AC, Fookes PG (2003) Engineering classification of karst ground conditions. Q J Eng Geol Hydrogeol 36:101-118. https:// doi.org/10.1144/1470-9236/2002-33

Wellmann JF, Horowitz FG, Schill E, Regenauer-Lieb K (2010) Towards incorporating uncertainty of structural data in $3 \mathrm{D}$ geological inversion. Tectonophysics 490(3-4):141-151. https://doi.org/10.1016/j. tecto.2010.04.022

Worthington SR (2009) Diagnostic hydrogeologic characteristics of a karst aquifer (Kentucky, USA). Hydrogeol J 17(7):16651678. https://doi.org/10.1007/s10040-009-0489-0

Željković I, Kadić A (2015) Groundwater balance estimation in karst by using simple conceptual rainfall-runoff model. Environ Earth Sci 74:6001-6015. https://doi.org/10.1007/s12665-015-4624-z

Živec T, Žibert M (2017) The 3D geological model of the Karavanke tunnel, using Leapfrog G. ITA - AITES WTC 2016. The World Tunnel Congress, San Francisco, April 2016

Zou YH, He JC, Ding ML (2012) Implicit simulation for threedimensional spatial morphology of geological body based on marching cubes algorithm. Appl Mech Mater 195-196:807-813. https://doi.org/10.4028/www.scientific.net/amm.195-196.807 